\title{
əNorth Atlantic Oscillation Effect on Interannual Variability in Winter Precipitation over the Gulf Stream
}

\author{
YUE SUN AND JiNG-WU LIU \\ Physical Oceanography Laboratory, Qingdao Collaborative Innovation Center of Marine Science and Technology, and \\ Ocean-Atmosphere Interaction and Climate Laboratory, Ocean University of China, Qingdao, China \\ SHANG-PING XIE \\ Scripps Institution of Oceanography, University of California, San Diego, La Jolla, California, and Physical Oceanography \\ Laboratory, and Ocean-Atmosphere Interaction and Climate Laboratory, Ocean University of China, Qingdao, China
}

(Manuscript received 10 July 2019, in final form 1 April 2020)

\begin{abstract}
In winter, the warm water of the Gulf Stream anchors a salient precipitation band. Previous studies suggested a close relationship between the sea surface temperature (SST) front and the precipitation band through sea level pressure (SLP) adjustment. This study uses 17 years of high-resolution precipitation observations to reveal that the variation in wintertime precipitation over the Gulf Stream is related to the North Atlantic Oscillation (NAO) at the interannual time scale. The moisture budget analysis shows that the climatological precipitation band is supported by the large evaporation from the Florida Current, mean flow, and synoptic moisture convergence within the boundary layer, with a negative contribution from mean-flow moisture advection by the prevailing northwesterlies. For interannual variability, by contrast, the negative contribution of mean-flow moisture advection significantly decreases due to anomalous southeasterlies west of the intensified Azores high at the positive NAO phase. The contributions from mean-flow moisture advection and mean and synoptic convergence vary greatly along the Gulf Stream. In addition, mean-flow and synoptic moisture convergences positively contribute to the precipitation band both in climatology and at the interannual time scale, indicative of a positive feedback between precipitation and boundary layer convergence. Our analysis suggests that the SLP adjustment mechanism across the SST front is still at work in interannual variability, and the variation of synoptic activities over the Gulf Stream plays an important role in modulating the frontal precipitation. By relating the frontal precipitation to the NAO, this study bridges small-scale air-sea interaction and large-scale atmospheric circulation.
\end{abstract}

\section{Introduction}

Satellites have revealed a salient precipitation band residing just over the Gulf Stream (Hobbs 1987; Minobe et al. 2008), which is the strongest oceanic western boundary current in the Northern Hemisphere (Tomczak and Godfrey 2003). In winter, the precipitation over the Gulf Stream releases a huge amount of latent heat into the atmosphere (Bane and Osgood 1989) and strongly influences regional climate and

¿ Denotes content that is immediately available upon publication as open access.

Corresponding author: Jing-Wu Liu, liujingwu@126.com, liujingwu@ouc.edu.cn. weather (Hamilton 1981; Forbes et al. 1997; Pfahl et al. 2015). Minobe et al. (2008) suggested a close relationship between the precipitation band and steep sea surface temperature (SST) front between the cold shelf water and the warm water of the Gulf Stream.

Minobe et al. (2008) proposed a mechanism of sea level pressure (SLP) adjustment (Lindzen and Nigam 1987) to link the Gulf Stream and the overlying precipitation band. The warm (cold) water of the Gulf Stream front heats (cools) the boundary layer air through turbulent mixing, and therefore causes relatively low (high) pressure and surface wind convergence (divergence). The induced convergence further anchors a precipitation band through the enhanced ascending motion over the warm water. The SLP adjustment mechanism explains the collocation between 
precipitation maxima and warm SSTs over the regions with strong SST fronts (e.g., Tokinaga et al. 2009; Xu et al. 2011; Xu and Xu 2015). From the perspective of synoptic scale, the Gulf Stream's warm water is also conducive to enhanced upward motion embedded in cyclones (Sheldon et al. 2017). The instability caused by the warm surface helps release latent heat and intensify the passing cyclones (Hirata et al. 2019). In addition, the sharp SST gradient produces the low-level baroclinicity favoring the intensification of cyclones (e.g., Vannière et al. 2017).

Although the climatological collocation of the Gulf Stream and precipitation band has been clarified in previous studies, it remains unclear how the precipitation varies with the surface prevailing winds at interannual scale. At this time scale, the North Atlantic Oscillation (NAO) is the most prominent and recurrent pattern of basin-scale atmospheric variability in the North Atlantic sector (Barnston and Livezey 1987), representing the dipolar variability in SLP between the Icelandic low and Azores high. The Gulf Stream is located on the southwest flank of the Azores high, where northwesterlies prevail in winter. The intensified Azores high during positive NAO phase weakens the wintertime surface northwesterlies over the Gulf Stream (Hurrell 1995).

Surface winds play an important role in the atmospheric response to SST fronts. When the winds flow from the cold to the warm water of SST fronts, the weakened stability strengthens turbulence within the marine atmospheric boundary layer and produces convective clouds (Kwon et al. 1998; Tokinaga et al. 2009; Liu et al. 2014). Fog usually forms when the warm and moist air flows from the warm to the cold water (Norris 1998; Norris and Iacobellis 2005). Spall (2007) suggested that weaker cross-frontal winds allow a more readily adjustment of near-surface air to the underlying SST gradient and result in a stronger SLP gradient. $\mathrm{Xu}$ and $\mathrm{Xu}$ (2015) showed that the SLP adjustment is stronger under weak cross-frontal winds for the East China Sea Kuroshio front from winter to spring.

Wintertime precipitation over the Gulf Stream may also be affected by atmospheric circulation through its influence on the moisture budget. Minobe et al. (2010) suggested that the precipitation over the Gulf Stream proper (between Cape Hatteras and the Grand Banks; Tomczak and Godfrey 2003) in winter is roughly balanced by local evaporation and moisture transported by the westerlies from the Florida Current (the leg of the Gulf Stream before reaching Cape Hatteras) region. Hurrell (1995) found negative anomalies in evaporation minus precipitation cover the Gulf Stream between positive and negative phases of NAO, but did not show a clear cross-SST-frontal structure due to the coarse resolution of the data used.

Satellite observations are capable of resolving the cross-frontal features (e.g., Minobe et al. 2008, 2010) but are not long enough to investigate the SST front effects on the local atmosphere at the interannual time scale. Sasaki and Yamada (2018) found that shaper SST gradient of the East China Sea Kuroshio intensifies the precipitation within the mei-yu-baiu band in June. In contrast, the wintertime precipitation over the Gulf Stream is produced by intermittent storms traveling along the storm track (O'Neill et al. 2017). Interannual to decadal variations of the SST fronts affect the location and intensity of the wintertime storm tracks over the frontal zone (e.g., Joyce et al. 2009; Nakamura et al. 2012; Taguchi et al. 2012; O'Reilly and Czaja 2015). The SST variations near the Gulf Stream influence the passing cold fronts and the convective precipitation (Hand et al. 2014). Stratiform rather than convective precipitation dominates the wintertime precipitation over the Gulf Stream. The interannual variation in the narrow precipitation band over the Gulf Stream remains to be investigated.

The present study investigates the interannual variation in wintertime precipitation over the Gulf Stream based upon 17-yr precipitation observations at $0.25^{\circ}$ resolution. The results show that the interannual variation of the precipitation exhibits a cross-frontal pattern clearly associated with the Gulf Stream. Moisture budget analysis based upon reanalysis data reveals that the NAO-related circulation and synoptic activities substantially alter the moisture balance over the Gulf Stream in winter. In addition, the wintertime NAO modulates the strength of SLP adjustment and synoptic activities over the Gulf Stream. Previous studies suggested the importance of the air-sea interactions at $\sim 100-\mathrm{km}$ scale on basin-scale atmospheric circulations by smoothing out strong SST gradients in numerical experiments (e.g., Taguchi et al. 2009; Small et al. 2014; Ma et al. 2015, 2016; Kuwano-Yoshida and Minobe 2017). Our study relates the precipitation over the Gulf Stream to the NAO in observations and helps to bridge the atmospheric circulation variability at the SST-frontal and basin scales.

We organize the rest of the paper as follows. Section 2 describes the data and method. Section 3 presents the wintertime atmospheric and oceanic conditions of the Gulf Stream. Section 4 investigates the interannual variations of the precipitation, the related atmospheric circulations, and moisture budget. Section 5 discusses the variations in SLP adjustment and synoptic activities related to NAO. Section 6 presents conclusions with discussion. 


\section{Data and method}

We employ high-resolution satellite observations and reanalysis data from 1999 to 2015, and refer to average values of December-February (DJF) as wintertime mean.

\section{a. Satellite observations}

We use the Tropical Rainfall Measuring Mission (TRMM) Multisatellite Precipitation Analysis (TMPA; https://storm.pps.eosdis.nasa.gov/storm/) to map precipitation over the Gulf Stream in DJF. The TMPA feeds on precipitation estimates from multiple satellites on a $0.25^{\circ} \times 0.25^{\circ}$ grid (Huffman et al. 2007). TMPA is capable of revealing the structure of precipitation bands over the Gulf Stream (Feng et al. 2017; O'Neill et al. 2017).

The Cross-Calibrated Multi-Platform (CCMP; http:// www.remss.com/measurements/ccmp/) data on a $0.25^{\circ} \times$ $0.25^{\circ}$ grid combine satellite and in situ observations of surface winds (Atlas et al. 2011). The CCMP has been used to study the atmospheric effects of the SST front and mesoscale ocean eddies in the Kuroshio-Oyashio confluence region (Wang and Oey 2016; Sugimoto et al. 2017).

We also obtain SST from the Advanced Very HighResolution Radiometer (AVHRR) infrared satellite on a $0.25^{\circ} \times 0.25^{\circ}$ grid (https://eastcoast.coastwatch.noaa.gov/ cw_avhrr.php; Ducet et al. 2000) and water vapor path from the Special Sensor Microwave Imager (SSM/I) and the Special Sensor Microwave Imager Sounder (SSMIS) on a $1^{\circ} \times 1^{\circ}$ grid (http://www.remss.com/missions/ssmi/; Wang and Hankes 2016). The NAO index is obtained from the NOAA Climate Prediction Center (https:// www.cpc.ncep.noaa.gov; Barnston and Livezey 1987).

\section{b. ECMWF operational analysis}

SLP, geopotential height, horizontal wind, vertical motion, specific humidity, and temperature at 2-m height are from the ERA5 data on a $0.25^{\circ} \times 0.25^{\circ}$ grid (Copernicus Climate Change Service 2017; Hersbach et al. 2018). The evaporation and reanalysis precipitation are obtained from the forecast fields of ERA5 to balance the moisture budget equation. The 6-hourly ERA5 data are used to diagnose the synoptic activity and its effect in moisture budget (Seager and Henderson 2013).

\section{c. Moisture budget analysis}

We employ moisture budget analysis following Trenberth and Guillemot (1995) and Seager et al. (2010):

$$
\begin{aligned}
\rho_{w} g(\bar{P}-\bar{E}) & =-\int_{0}^{p_{s}} \nabla \cdot(\overline{\mathbf{u} q}) d p+\text { residual } \\
& =-\int_{0}^{p_{s}} \nabla \cdot(\overline{\mathbf{u}} \bar{q}) d p-\int_{0}^{p_{s}} \nabla \cdot\left(\overline{\mathbf{u}^{\prime} q^{\prime}}\right) d p+\text { residual } \\
& =-\underbrace{-\int_{0}^{p_{s}}(\overline{\mathbf{u}} \cdot \nabla \bar{q}) d p}_{\mathrm{ADV}_{\text {Mean }}} \underbrace{-\int_{0}^{p_{s}}(\bar{q} \nabla \cdot \overline{\mathbf{u}}) d p}_{\mathrm{COV}_{\text {Mean }}} \underbrace{-\int_{0}^{p_{s}}\left(\overline{\mathbf{u}^{\prime} \cdot \nabla q^{\prime}}\right) d p}_{\mathrm{ADV}_{\mathrm{Syn}}} \underbrace{-\int_{0}^{p_{s}}\left(\overline{q^{\prime} \nabla \cdot \mathbf{u}^{\prime}}\right) d p}_{\mathrm{COV}_{\mathrm{Syn}}}+\underbrace{\text { residual }}_{\mathrm{RES}},
\end{aligned}
$$

where overbars and primes denote the monthly mean and synoptic values, respectively; $g$ is the gravity acceleration; $P$ and $E$ are precipitation and evaporation, respectively; $\rho_{w}$ and $q$ are density of liquid water and specific humidity, respectively; $\mathbf{u}$ is the horizontal wind vector; and $p$ is pressure with subscript $s$ denoting the surface value. The difference between precipitation and evaporation is in balance with vertically integrated mean-flow moisture flux convergence, synoptic moisture flux convergence, and residual (RES). The mean-flow and synoptic moisture flux convergences can both be decomposed into two parts that are related to the moisture advection $\left(\mathrm{ADV}_{\text {Mean }}, \mathrm{ADV}_{\mathrm{Syn}}\right)$ and the moisture convergence $\left(\mathrm{COV}_{\text {Mean }}, \mathrm{COV}_{\text {Syn }}\right)$, respectively.

The monthly terms are based on ERA5monthly data, and the synoptic terms are based on the high-pass filtered data of 6-hourly ERA5. The cutoff period for the high-pass filter is 8 days following Sampe et al. (2010); the results are not sensitive to the choice of cutoff period. The residual on the right-hand side of Eq. (1) mainly originates from the moisture imbalance in the reanalysis data and contribution from time scale gap between 8 days and 1 month.

Continual changes in the observations over time lead to spurious changes in the moisture field and affect the hydrological cycle in the assimilating models. The observational uncertainties also contribute to the hydrological imbalance in the reanalysis data (Trenberth et al. 2011). The data from ECMWF appear to be reliable in precipitation minus evaporation (Trenberth and Guillemot 1995). The ERA has also been used for the global (Berrisford et al. 2011) and regional atmospheric moisture budget analysis (Tietäväinen and Vihma 2008; Jakobson and Vihma 2010; Salah et al. 2018). 


\section{d. Latent heat flux analysis}

The bulk formula of latent heat flux can be expressed as

$$
Q_{E}=\rho_{a} L C_{E} W\left[q_{s}(T)-\mathrm{RH} q_{s}(T-\Delta T)\right],
$$

where $\rho_{a}$ is surface air density, $L$ is the latent heat of evaporation, $C_{E}$ is the effective drag coefficient $\left(C_{E}=\right.$ $\left.1.4 \times 10^{-3}\right), W$ is the surface wind speed, $T$ is the SST, $\Delta T$ is the SST minus surface air temperature (SAT; Philander and Seigel 1985), $q_{s}(T)$ is the saturated specific humidity following the Clausius-Clapeyron equation, and $\mathrm{RH}$ is the surface relative humidity. The atmospheric forcing on the latent heat flux due to the changes in wind speed can be obtained by linearizing (2),

$$
Q_{\mathrm{EW}}^{\prime}=\overline{Q_{E}} \frac{W^{\prime}}{\bar{W}}
$$

which is commonly known as the wind-evaporationSST feedback (Xie and Philander 1994). The overbar and prime denote the mean and perturbation, respectively. We can also obtain the effect of SST minus SAT by

$$
Q_{E \Delta T}^{\prime}=\overline{Q_{E}} \frac{\Delta T^{\prime}}{\overline{\Delta T}}
$$

\section{e. Statistical significance}

The significance of correlations is tested by using effective degrees of freedoms (e.g., Pyper and Peterman 1998; $\mathrm{Li}$ et al. 2012). The critical value for the null hypothesis that the correlation between two time series is different from zero at a significance level can be derived using the $t$ distribution for two-tailed tests (Zar 1984). Statistical significances of regression coefficients are gauged by the Student's $t$ test to determine whether the slopes are nonzero. We estimate the effective number of the sample size by taking into account the autocorrelation based on the lag-1 autocorrelation (e.g., Bartlett 1935; Zwiers and von Storch 1995).

\section{Wintertime climatology}

\section{a. Background conditions}

The Gulf Stream flows along the east coast of North America, leaves Cape Hatteras, and then flows to the Grand Banks. The surface currents carry the warm water from lower latitudes with strong SST gradients (Fig. 1a). In boreal winter, the background northwesterlies blow from the cold continent to the relatively warm and moist sea surface. The northwesterlies converge and diverge over the warm and cold flanks of the
SST front, respectively (Fig. 1b). The surface convergence anchors a deep upward motion and a precipitation band, which peaks at $10 \mathrm{~mm} \mathrm{day}^{-1}$ over the Gulf Stream proper (contours in Fig. 2a and color in Fig. 1a). The collocation among precipitation maxima, wind convergence, and the SLP Laplacian maxima is consistent with the SLP adjustment mechanism (Fig. 1; Minobe et al. 2008). We hereafter use the $7 \mathrm{mmday}^{-1}$ contour of TMPA precipitation between $80^{\circ}$ and $45^{\circ} \mathrm{W}$ to identify the wintertime precipitation band (white contour in Fig. 1a). Note that the TMPA precipitation peak over the Gulf Stream proper is somewhat greater than that of Minobe et al. (2010, their Fig. 6a) based on TRMM between 2002 and 2006, partly because of the different periods of average (not shown). This indicates a strong interannual variation in winter precipitation over the Gulf Stream.

\section{b. Moisture budget}

We examine the forecast precipitation from ERA5. Within the observed precipitation band, the forecast precipitation reaches its peak at $8 \mathrm{~mm} \mathrm{day}^{-1}$, $\sim 2 \mathrm{~mm} \mathrm{day}^{-1}$ lower than TMPA precipitation maximum. In general, the spatial pattern of precipitation from the forecast data of ERA5 (Fig. 3a) resembles that of TMPA in climatology (Fig. 1a). Further, the correlation coefficient between the DJF area-mean precipitation fluctuations over the Gulf Stream of TMPA and ERA5 reaches 0.80 with significance at $95 \%$ confidence level (not shown). The resemblance between precipitation fluctuations in reanalysis and observation gives us the confidence in using ERA5 to study the interannual variation in precipitation by moisture budget analysis.

Under strong northwesterlies, large thermal and moisture contrasts exist between the warm seawater and the above continental air masses. Thus, evaporation peaks right over the Florida Current and the western Gulf Stream proper (Fig. 3d). The huge amount of evaporation supports the precipitation, which peaks downstream of the evaporation maxima. Figure $3 \mathrm{c}$ shows the mean-flow moisture advection term in Eq. (1), which is negative west of $55^{\circ} \mathrm{W}$ over the Gulf Stream, suggesting that the background circulation transports moisture from the Gulf Stream downstream. The vertical cross-frontal transection suggests that the mean-flow moisture advection is mostly confined below $800 \mathrm{hPa}$ (contours in Fig. 2d).

The mean-flow moisture convergence term also contributes to the precipitation band over the Gulf Stream, but with a much smaller magnitude (Fig. 3b). The vertical cross-frontal transection suggests that the meanflow moisture convergence below $850 \mathrm{hPa}$ is important (contours in Fig. 2c). The positive contribution of the 
(a) Precip. $\left(\mathrm{mm}\right.$ day $\left.{ }^{-1}\right), \mathrm{SST}\left({ }^{\circ} \mathrm{C}\right)$

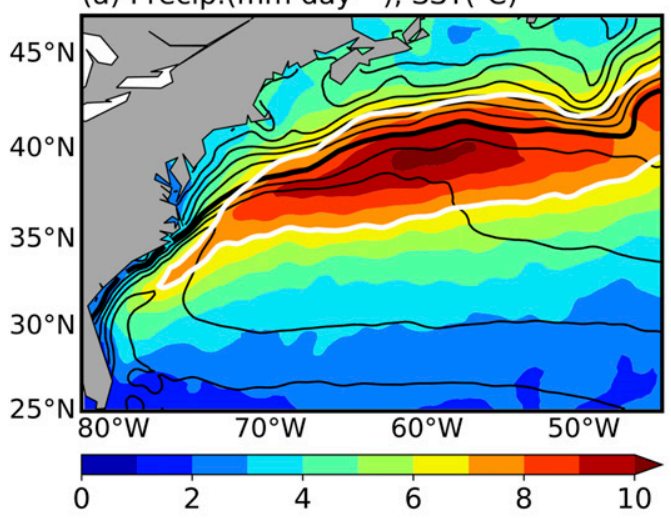

(c) $\triangle \operatorname{SLP}\left(10^{-9} \mathrm{~Pa} \mathrm{~m}^{-2}\right)$

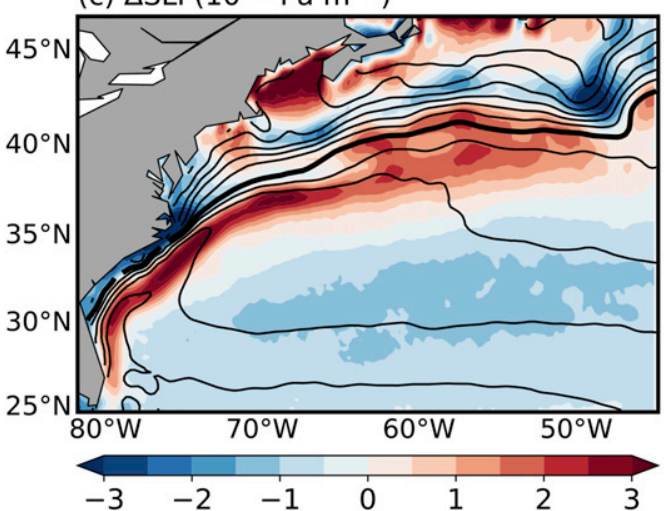

(b) $\vec{u}_{10 m}\left(\mathrm{~m} \mathrm{~s}^{-1}\right),-\nabla \cdot \vec{u}_{10 m}\left(10^{-6} \mathrm{~s}^{-1}\right) \rightarrow 15$

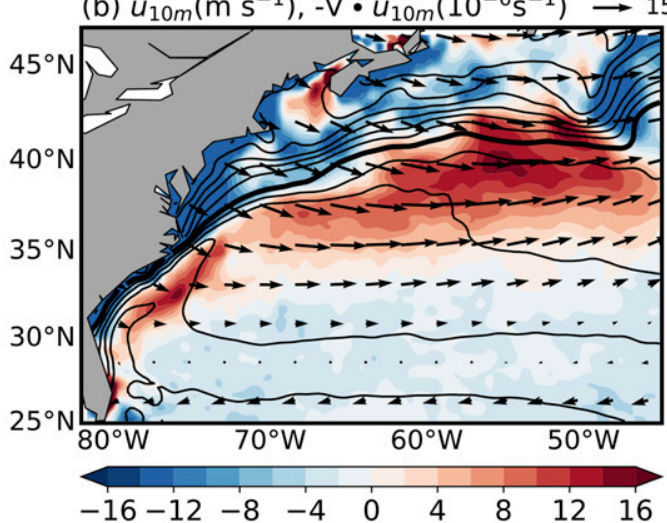

(d) $\sigma$ (Precip.) $\left(\mathrm{mm} \mathrm{day}^{-1}\right)$

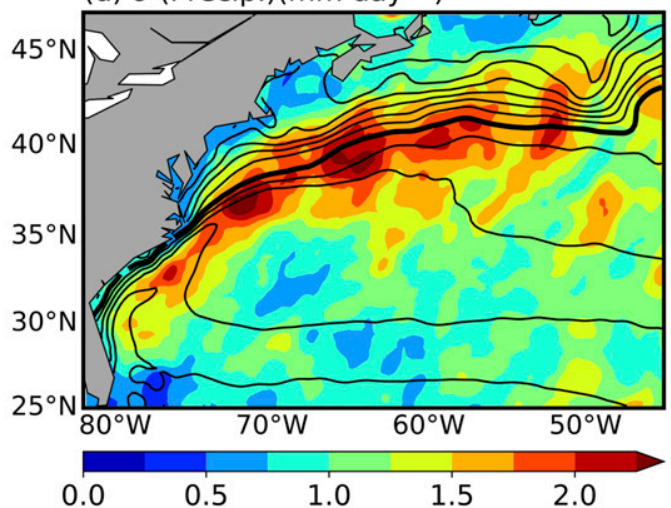

FIG. 1. Wintertime (DJF) climatology (1999-2015, the same hereinafter): (a) TMPA precipitation (color shading, $\mathrm{mm} \mathrm{day}^{-1}$; white contour indicates $7 \mathrm{~mm} \mathrm{day}^{-1}$, the same hereinafter), (b) CCMP wind velocities (vectors, $\mathrm{m} \mathrm{s}^{-1}$ ) at $10 \mathrm{~m}$ and their convergence (color shading, $10^{-6} \mathrm{~s}^{-1}$ ), (c) SLP Laplacian in the ERA5 reanalysis (color shading, $10^{-9} \mathrm{~Pa} \mathrm{~m}^{-2}$ ), and (d) the standard deviation (color shading, $\mathrm{mm} \mathrm{day}^{-1}$ ) of TMPA precipitation at the interannual time scale. The superimposed black contours are AVHRR SST at $2^{\circ} \mathrm{C}$ interval. The $16^{\circ} \mathrm{C} \mathrm{SST} \mathrm{contour} \mathrm{is} \mathrm{thickened}$ (the same hereinafter).

convergence term indicates a positive feedback between the convergence and precipitation over the Gulf Stream. The atmospheric convergence induced by the SST front converges moisture and strengthens precipitation, and in turn is intensified by the latent heat released by precipitation.

The contribution of synoptic moisture convergence peaks right over the Gulf Stream (Fig. 3e), consistent with the frequent storms along the Gulf Stream (Fig. 4a). The synoptic moisture advection term shows an interesting pattern that is positive (negative) over the northwest (southeast) flank of the SST front, and decreases the precipitation over the Gulf Stream; see Fig. 3f. The synoptic moisture convergence and advection terms are caused by synoptic activities, which are measured by the root-mean-square (rms) of $10-\mathrm{m}$ meridional wind velocity fluctuations, traveling along the storm track with the maximum along the SST front in winter (Fig. 4a). The high-frequency synoptic activities act to converge moisture along the SST front, and transport moisture from the warm flank of SST front to the cold flank.

The contributions of evaporation and mean-flow moisture convergence and advection account for $118.8 \%, 11.0 \%$, and $-24.8 \%$ of the average precipitation over the precipitation band (white contour in Fig. 1a), respectively. The synoptic moisture convergence and advection account for $27.3 \%$ and $-37.8 \%$, respectively. This suggests that the precipitation band over the Gulf Stream generally originates from the upstream evaporation west of $60^{\circ} \mathrm{W}$. The contribution of synoptic moisture convergence is greater than that of mean flow, and the magnitude of synoptic moisture advection is larger than that of mean flow. Equation (1) is generally balanced in DJF ERA5 data. This validates our application of moisture budget analysis using ERA5. The residual term is $0.40 \mathrm{~mm} \mathrm{day}^{-1}$ on average, accounting for $5.6 \%$ of the mean precipitation (Fig. $3 \mathrm{~g}$ ). 


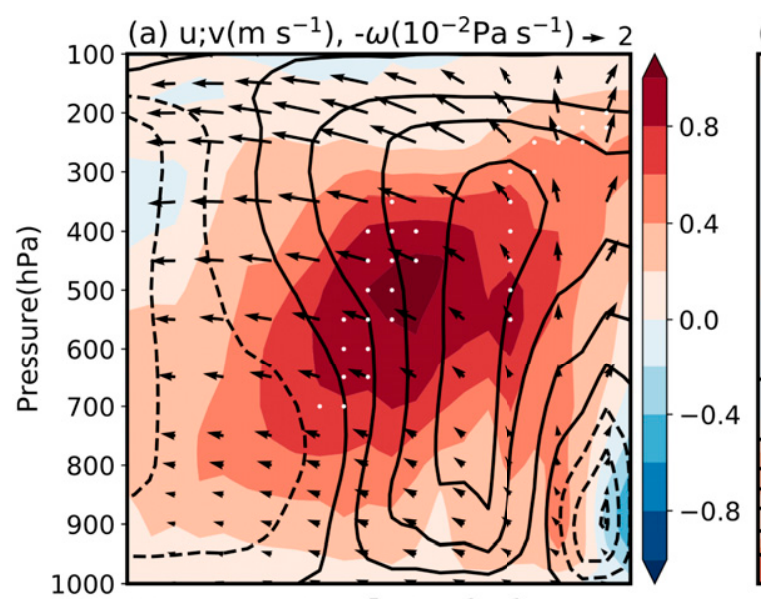

(b) $\mathrm{q}\left(\mathrm{g} \mathrm{kg}^{-1}\right)$
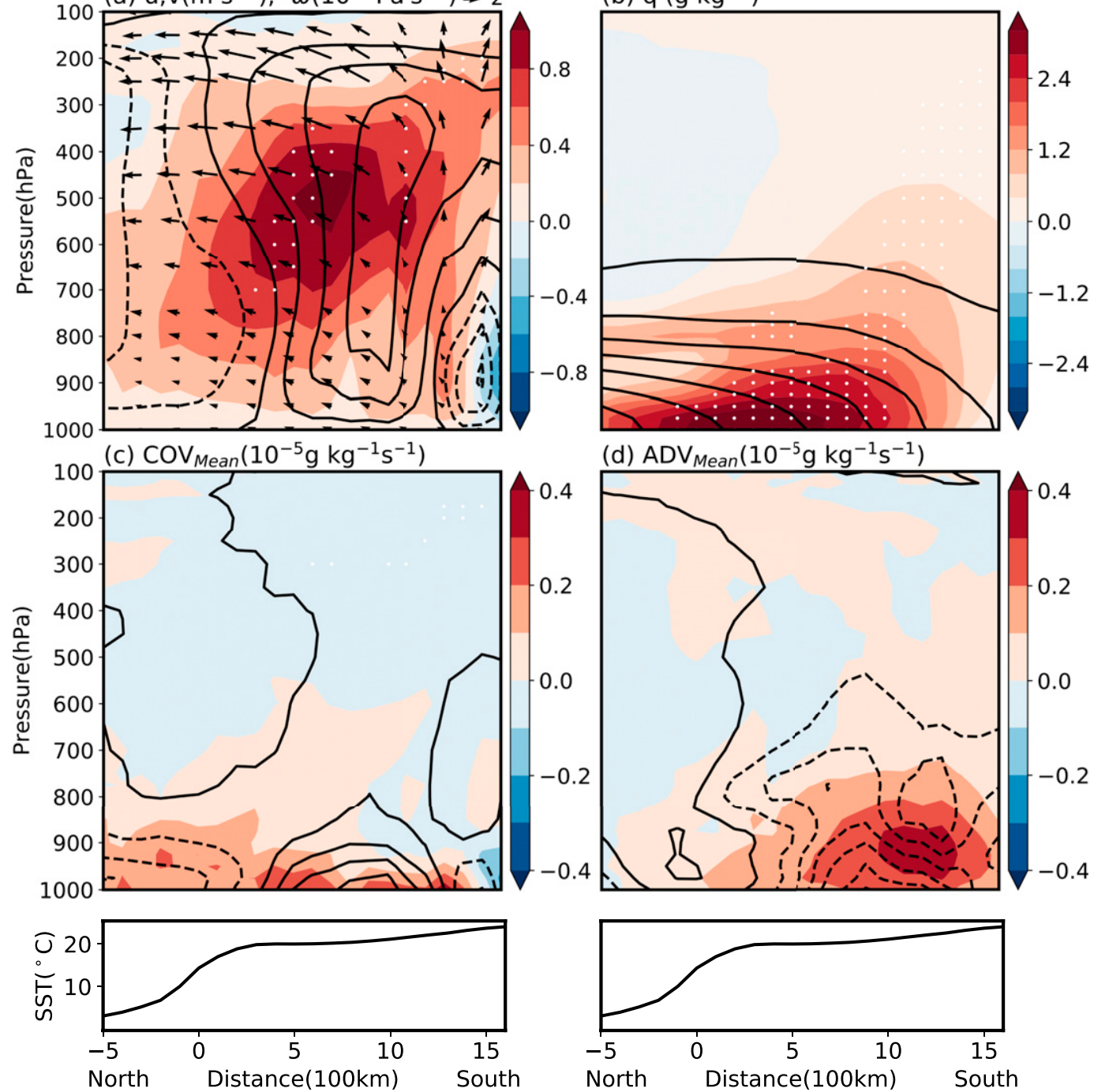

(d) $A D V_{\text {Mean }}\left(10^{-5} \mathrm{~g} \mathrm{~kg}^{-1} \mathrm{~s}^{-1}\right)$
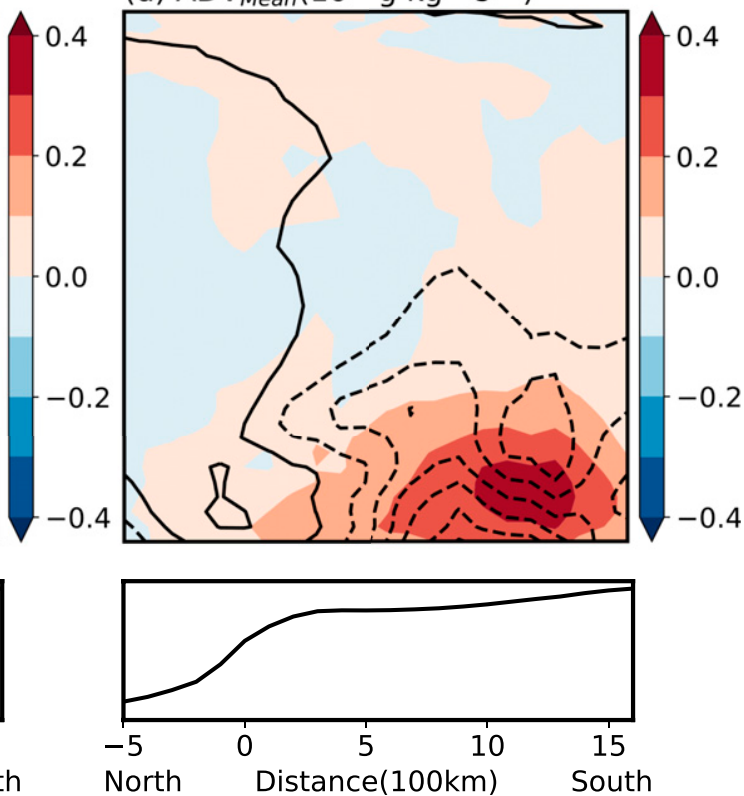

FIG. 2. The cross-frontal transections of climatology (contours) and regressions against the PC1 (color shading): (a) vertical motion $\left(-10^{-2} \mathrm{~Pa} \mathrm{~s}^{-1}\right)$, (b) specific humidity $\left(\mathrm{g} \mathrm{kg}^{-1}\right)$, (c) mean-flow moisture convergence $\left(10^{-5} \mathrm{~g} \mathrm{~kg}^{-1} \mathrm{~s}^{-1}\right)$, and (d) mean-flow moisture advection $\left(10^{-5} \mathrm{~g} \mathrm{~kg}^{-1} \mathrm{~s}^{-1}\right)$ averaged between $75^{\circ}-50^{\circ} \mathrm{W}$. The vectors in (a) represent the regressed horizontal winds $\left(\mathrm{m} \mathrm{s}^{-1}\right)$ with left and up arrows indicating easterly and southerly, respectively. The lines in the bottom panels of (c) and (d) are cross-frontal transection of SST averaged between $75^{\circ}$ and $50^{\circ} \mathrm{W}$. All the variables are composited referenced to the Gulf Stream SST front center $\left(x=0 ; 16^{\circ} \mathrm{C} \mathrm{SST}\right.$ contour in Fig. 1a) according to the minimal distance $(\times 100 \mathrm{~km})$ to the front center, with positive $x$ indicating the southeast. The regressions with significance at the $95 \%$ confidence level are stippled (the same hereinafter).

\section{Interannual variations}

We examine the interannual standard deviation of DJF precipitation after removing the linear trend (Fig. 1d). The comparison between Figs. 1a and 1d shows that the magnitude of interannual variation is about a quarter of the DJF mean. The peak of precipitation climatology lies on the warm flank of SST front, while the interannual precipitation variability peaks right over the SST front. A closer examination of Fig. 1d shows that the standard deviation is not as smooth as the mean precipitation over the Gulf Stream, probably due to the uneven sampling of the satellite observations.

\section{a. EOF analysis}

Empirical orthogonal function (EOF) analysis is applied to the DJF TMPA precipitation over $30^{\circ}-45^{\circ} \mathrm{N}$, $80^{\circ}-50^{\circ} \mathrm{W}$ after removing the linear trend. The leading EOF (EOF1) explains $32 \%$ of the variance and peaks just over the Gulf Stream proper (Fig. 5a). This suggests that EOF1 generally represents the precipitation 
(a) $\mathrm{P}\left(\mathrm{mm}\right.$ day $\left.^{-1}\right)$

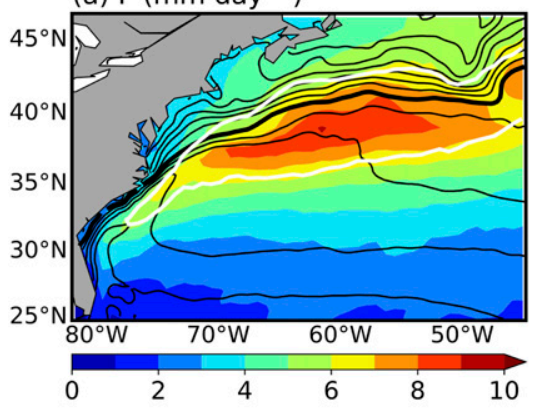

(d) $\mathrm{E}, \mathrm{u}_{10 \mathrm{~m}}\left(\mathrm{~m} \mathrm{~s}^{-1}\right)$

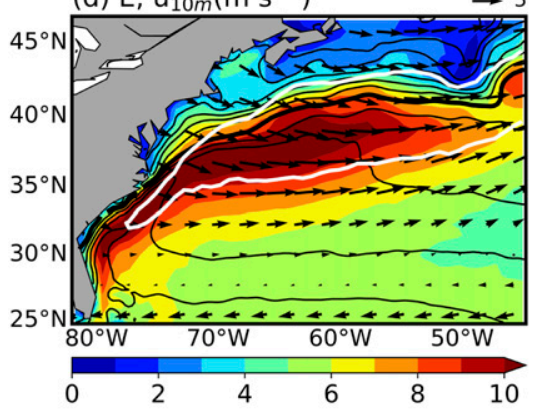

(b) $\mathrm{COV}_{\text {Mean }}$

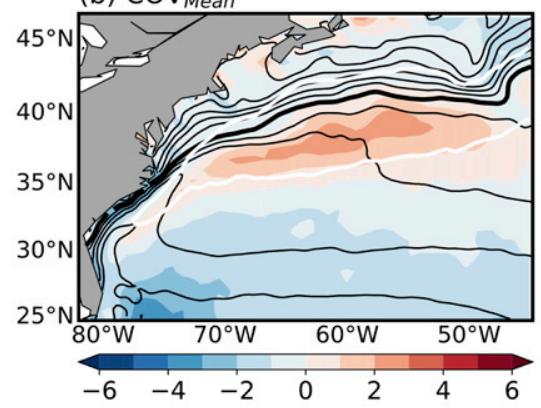

(e) $\operatorname{cov}_{\text {Syn }}$

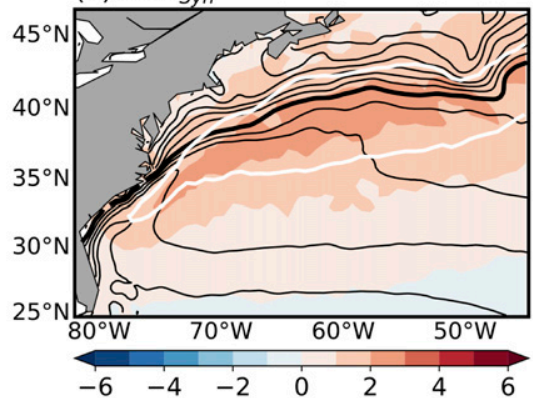

(g) RES

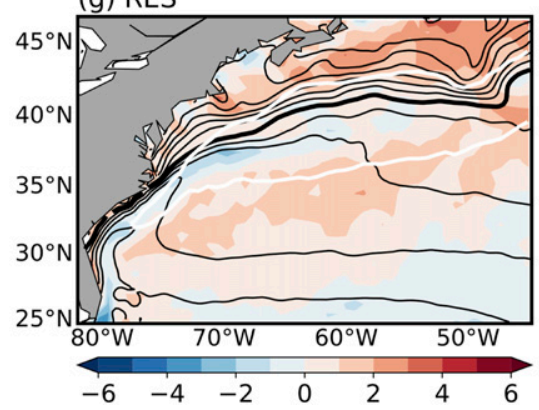

(c) $A D V_{\text {Mean }}$

(f) $A D V_{S y n}$

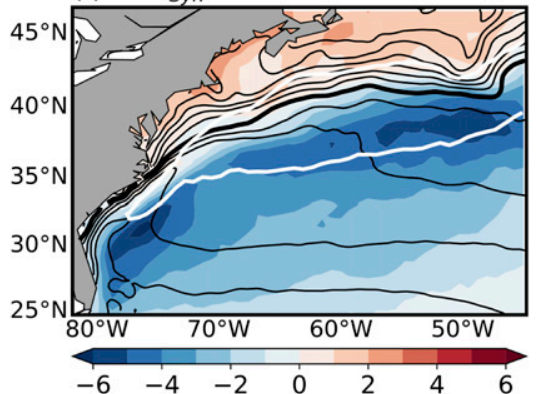

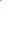

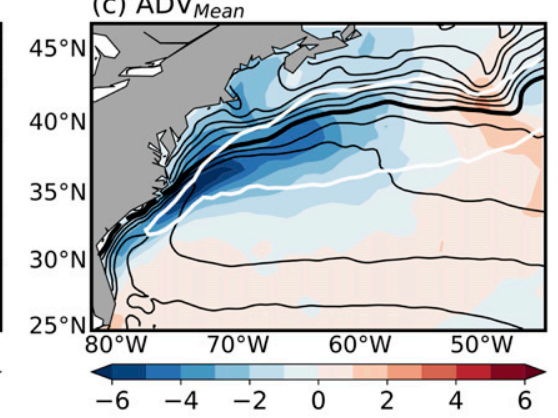

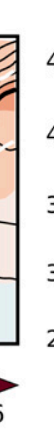

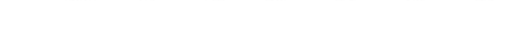


(a) $r m s\left(v^{\prime}{ }_{10 m}\right)\left(\mathrm{m} \mathrm{s}^{-1}\right)$

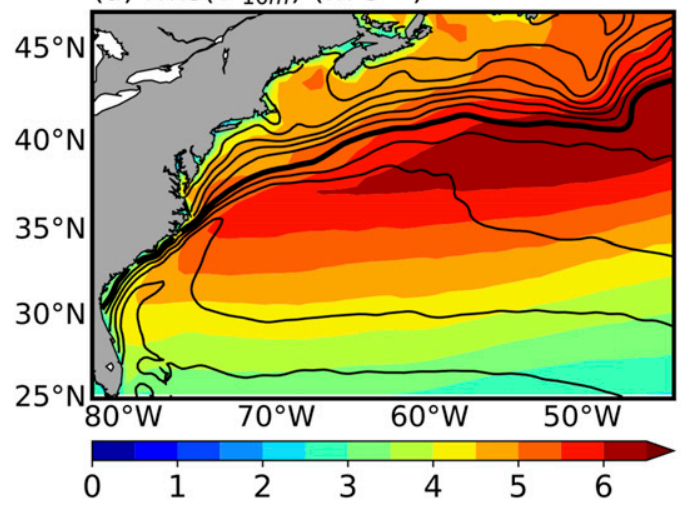

(b) Reg rms $\left(\mathrm{v}^{\prime}{ }_{10 \mathrm{~m}}\right)\left(\mathrm{m} \mathrm{s}^{-1}\right)$

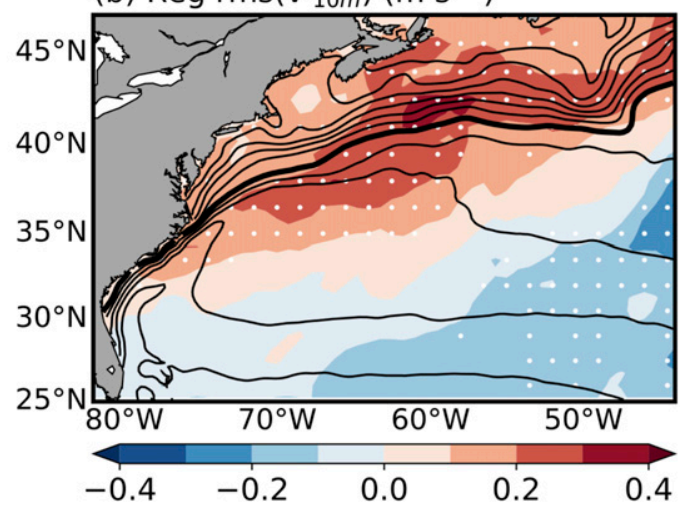

FIG. 4. Root-mean-square of 10-m meridional wind velocity fluctuation (color shading, $\mathrm{m} \mathrm{s}^{-1}$ ): (a) climatology and (b) regression against the $\mathrm{PC} 1$.

NAO, we further regress DJF TMPA precipitation onto the DJF NAO index. The result shows that the regressed precipitation peaks just over the Gulf Stream proper (Fig. 7a) and shares a similar pattern with EOF1 (Fig. 5a). In addition, the cross-frontal ascending motion associated with the precipitation band becomes much stronger, especially in the middle of the troposphere (color in Fig. 2a). The weakened prevailing winds dominate in the entire troposphere within $1000 \mathrm{~km}$ of the SST front center (vectors in Fig. 2a).

We regress the water vapor path from the satellite observations and reanalysis onto PC1 (Fig. 8). Figure 8a shows that the water vapor path increases by $\sim 0.9 \mathrm{~mm}$ downstream of the Gulf Stream proper. The increase in water vapor path primarily concentrates below $800 \mathrm{hPa}$ (color shading in Fig. 2b), indicative of the importance of processes within the atmospheric boundary layer.

\section{c. Moisture budget analysis}

Figure 9 shows ERA5 regressions of the terms in Eq. (1) onto PC1. Unlike EOF1, the regressed forecast precipitation does not show a well-defined pattern associated with the SST front (Fig. 9a). Specifically, the positive values of observed precipitation EOF1 extend
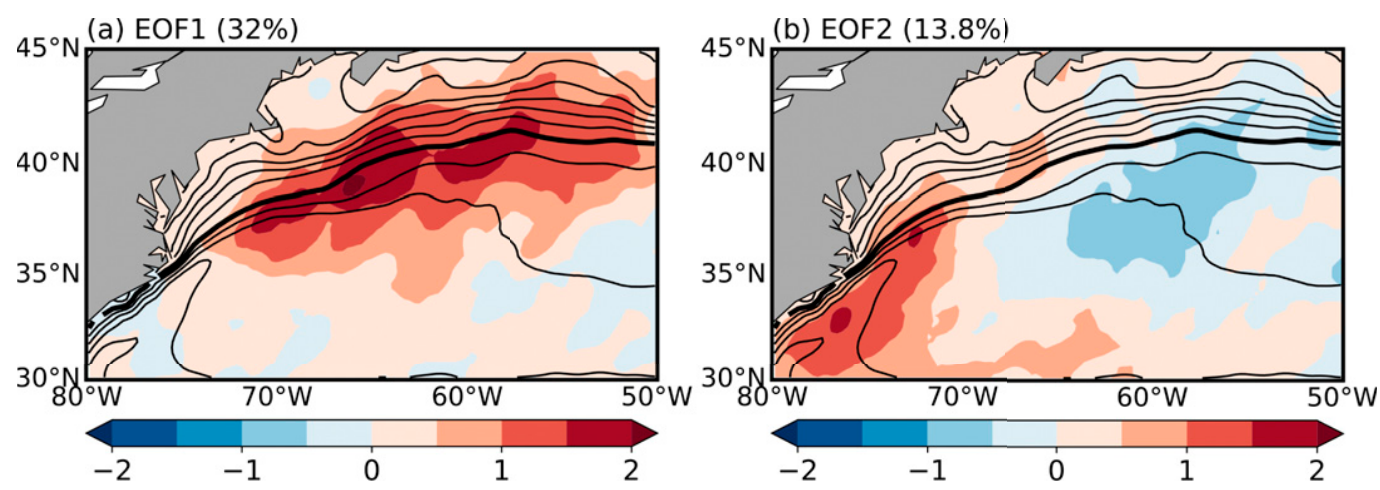

(c) Precip., PC1, NAOI

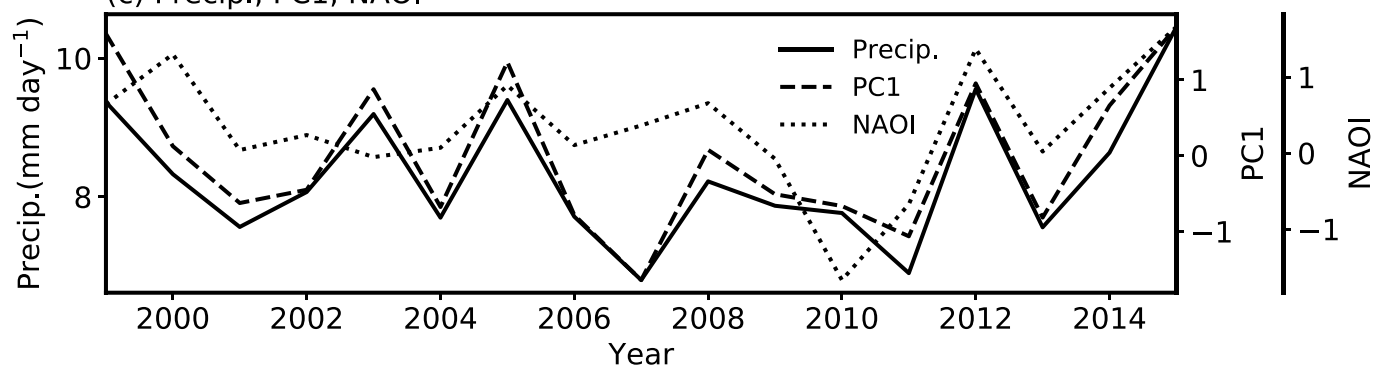

FIG. 5. The (a) first and (b) second EOFs (color shading, $\mathrm{mm} \mathrm{day}^{-1}$ ) of DJF TMPA precipitation. (c) Time series of precipitation averaged over the Gulf Stream (solid line, $\mathrm{mm} \mathrm{day}^{-1}$ ), standardized PC1 (dashed), and the NAO index (dotted). 
(a) Reg $Z_{500}$ onto $\mathrm{PC} 1(\mathrm{gpm})$

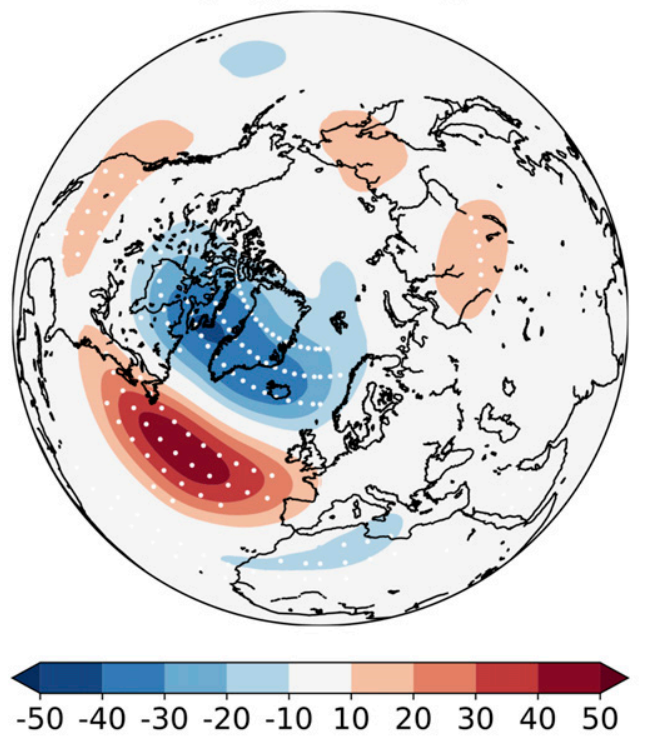

(c) Reg $Z_{500}$ onto NAOI(gpm)

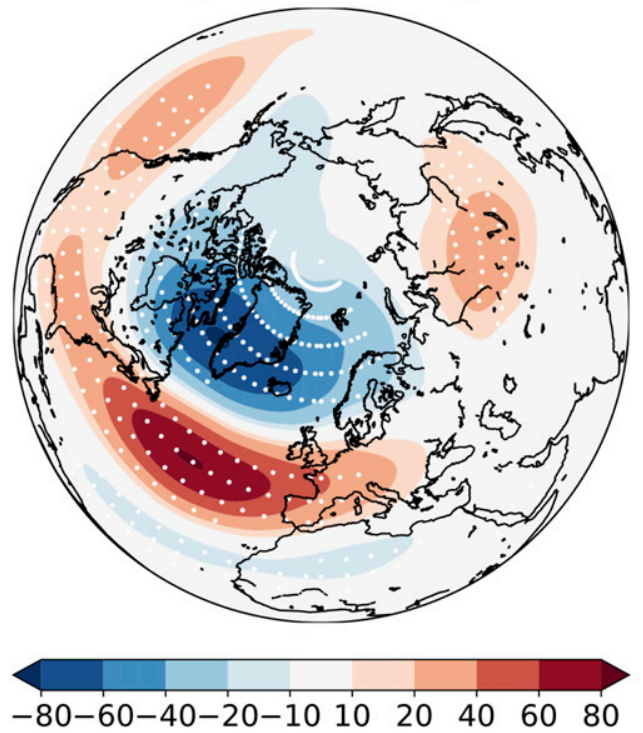

(b) Reg SLP onto PC1(hPa)

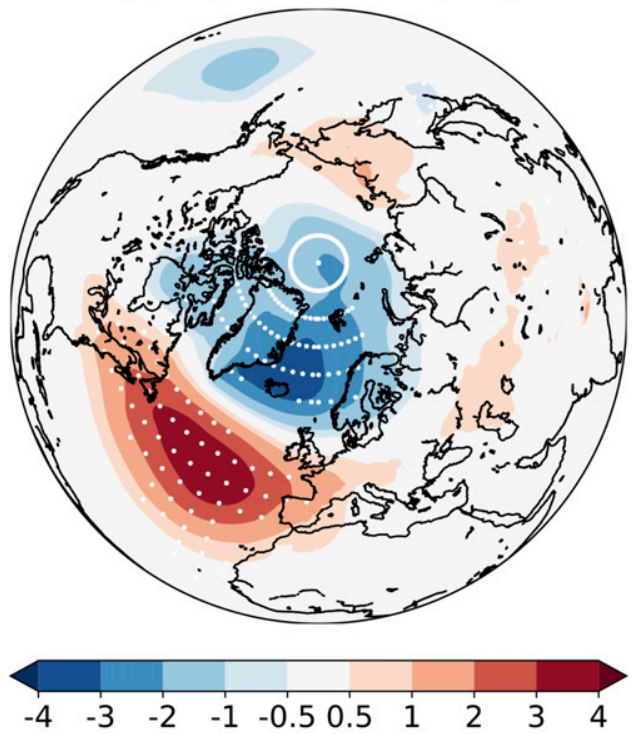

(d) Reg SLP onto NAOI(hPa)

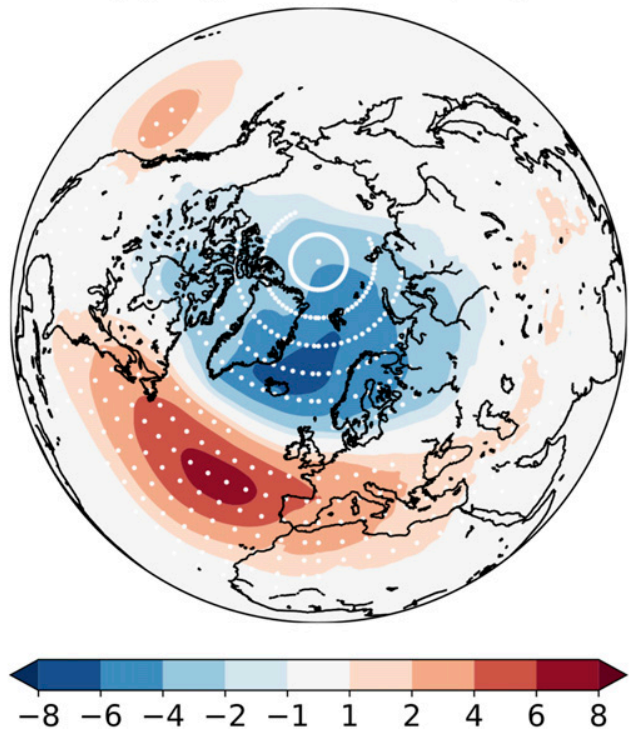

FIG. 6. (a),(b) Regressed DJF 500-hPa geopotential height (color shading, gpm) and SLP (color shading, hPa) onto PC1, respectively. (c),(d) Regressed DJF 500-hPa geopotential height (color shading, gpm) and SLP (color shading, hPa) onto the NAO index, respectively.

from $\sim 75^{\circ}$ to $50^{\circ} \mathrm{W}$ over the SST front (Fig. 5a), but the regressed ERA5 precipitation peaks at around $60^{\circ} \mathrm{W}$. This inconsistency suggests that the skill of reanalysis in simulating the interannual variations in precipitation is limited. However, regressed forecast precipitation is mostly positive over the SST front. Within the white rectangle in Fig. 9a, the average precipitation anomalies is $\sim 0.3 \mathrm{~mm} \mathrm{day}^{-1}$, smaller than that of EOF1 $\left(\sim 1 \mathrm{~mm} \mathrm{day}^{-1}\right)$.
Mean-flow moisture advection seems to be the most important for the interannual variations in precipitation near the Gulf Stream (Fig. 9c). The positive contribution of mean-flow moisture advection increases significantly east of $60^{\circ} \mathrm{W}$ (color shading in Fig. 9c). Mean-flow moisture advection also has a notable contribution west of $60^{\circ} \mathrm{W}$. Variations in mean-flow moisture advection are primarily confined below $800 \mathrm{hPa}$ (color shading in Fig. 2d). The correlation coefficient between PC1 and 
(a) Reg Precip. onto NAOI ( $\left.\mathrm{mm} \mathrm{day}^{-1}\right)$

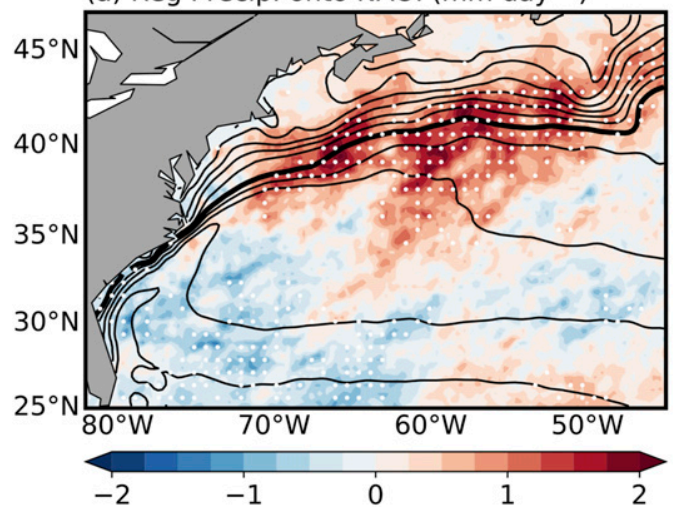

(b) Reg $\vec{u}_{10 m}\left(\mathrm{~m} \mathrm{~s}^{-1}\right),-\nabla \cdot \vec{u}_{10 m}\left(10^{-6} \mathrm{~s}^{-1}\right) \rightarrow 1$

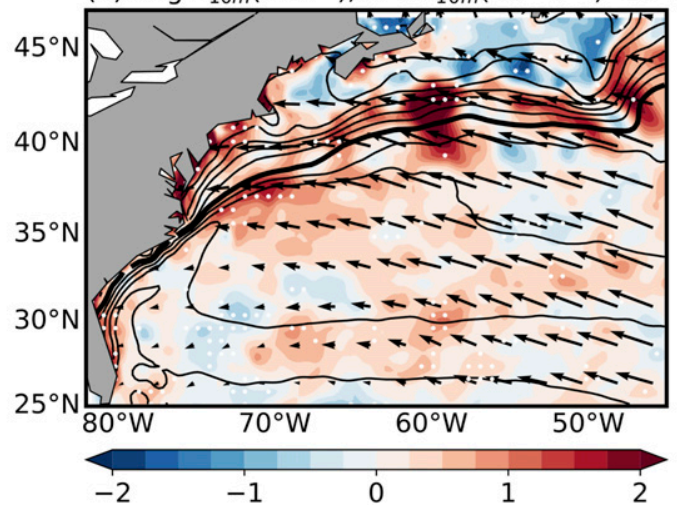

FIG. 7. Regressions of (a) TMPA precipitation and (b) CCMP $10-\mathrm{m}$ wind velocities $\left(\mathrm{m} \mathrm{s}^{-1}\right)$ and the $10-\mathrm{m}$ wind convergence (color shading, $10^{-6} \mathrm{~s}^{-1}$ ) onto the NAO index.

averaged mean-flow moisture advection over the white rectangle is 0.48 , which is significant at the $95 \%$ confidence level (Fig. 10).

Mean-flow moisture convergence positively contributes to the precipitation west of $55^{\circ} \mathrm{W}$ (Fig. 9b) where its climatological counterpart is also large (Fig. 3b). This is partly related to the intensified surface wind convergence along the SST front (color shading in Fig. 7b). The vertical transection of regressed mean-flow moisture convergence shows that the increase in convergence is mostly confined below $900 \mathrm{hPa}$ (color in Fig. 2c). Regression of synoptic moisture convergence is also positive along the SST front although with a smaller magnitude. Different from the mean-flow moisture convergence, the regressed synoptic moisture convergence suggests that the synoptic activities converge more moisture over the SST front (Fig. 9e). This is caused by the strengthened storm track over the SST front (Fig. 4b). Hurrell et al. (2003) showed that there are strengthened and north-shifted storm tracks during positive NAO. Synoptic moisture advection negatively contributes to the precipitation band, especially east of $65^{\circ} \mathrm{W}$ (Fig. 9f). This is also due to the strengthened synoptic activities over the SST front of the Gulf Stream.

Evaporation also acts to decrease precipitation associated with PC1 generally over the entire domain and peaks east of $60^{\circ} \mathrm{W}$ between $30^{\circ}$ and $40^{\circ} \mathrm{N}$ (Fig. 9d). The weakened evaporation during positive $\mathrm{PC} 1$ is related to the changes in near-surface circulation (Fig. 11). The anomalous southeasterlies associated with $\mathrm{PC} 1$ weaken the background northwesterlies and decrease the difference between SST and SAT (Figs. 11a and 11b). The weakened background winds and decrease in SST SAT both contribute to the reduction in evaporation that are quantified using Eqs. (3) and (4). Figures 11c and 11d show the effects of changes in surface wind speed and SST-SAT on evaporation, respectively. The results show that the pattern of the evaporation change

(a) Reg SSMI/SSMIS water vapor path $(\mathrm{mm})$

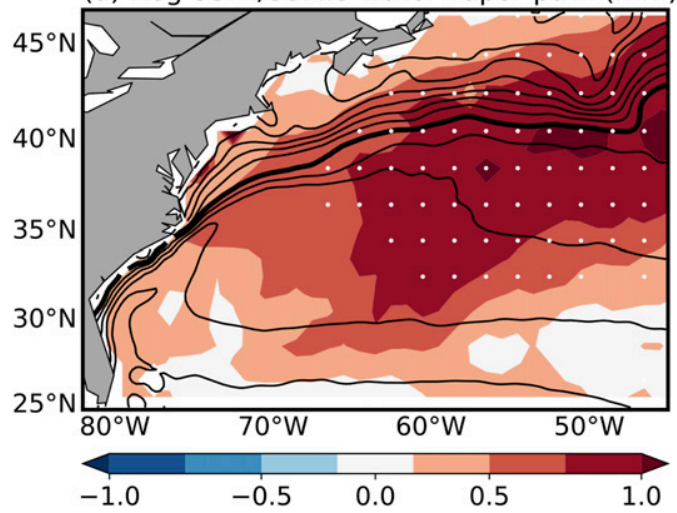

(b) Reg ERA water vapor path $(\mathrm{mm})$

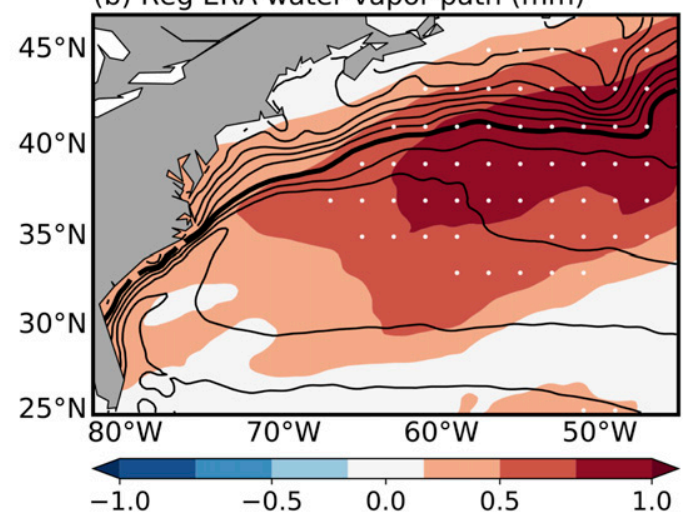

FIG. 8. Regressions of water vapor path (color shading, mm) onto PC1 based on (a) SSM/I and SSMIS and (b) ERA5. 
(a) Reg P (mm day $\left.{ }^{-1}\right)$

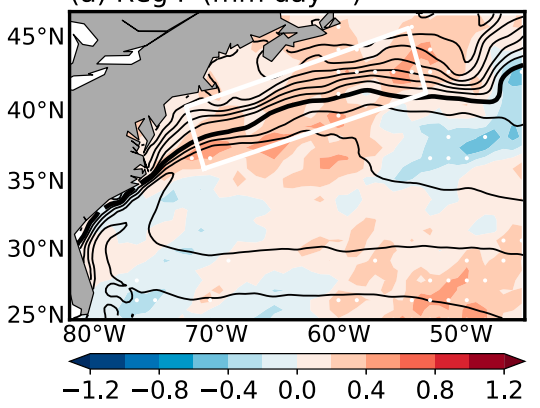

(d) Reg $\mathrm{E}$

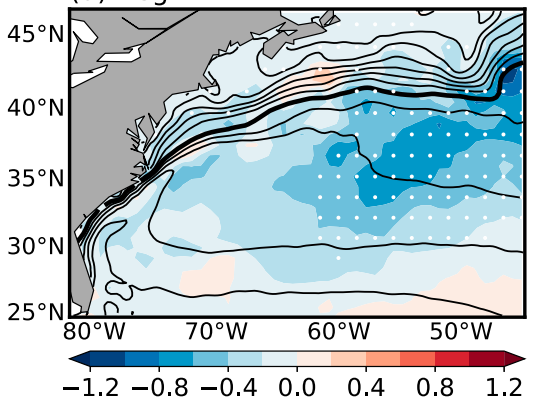

(b) Reg COV

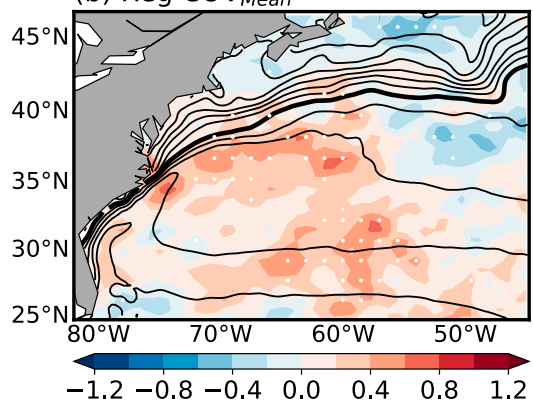

(e) Reg $\operatorname{COV}_{\text {syn }}$

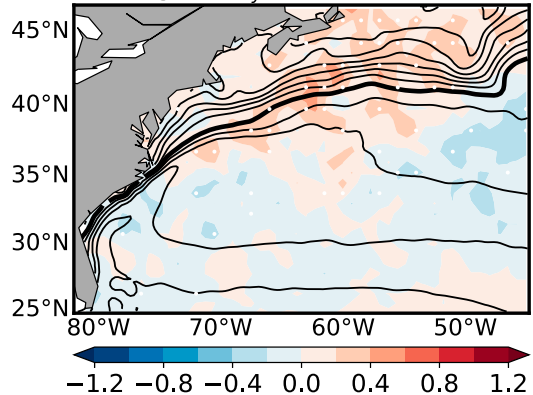

(g) Reg RES

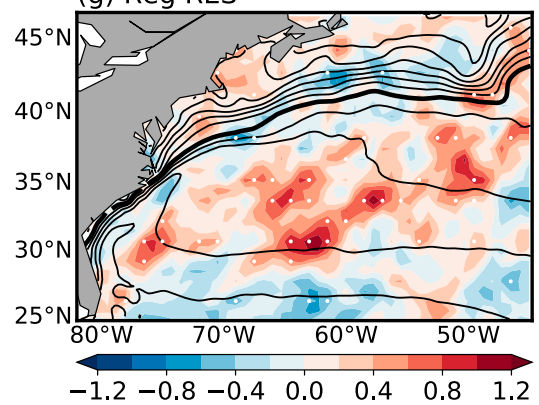

(c) Reg ADV Mean

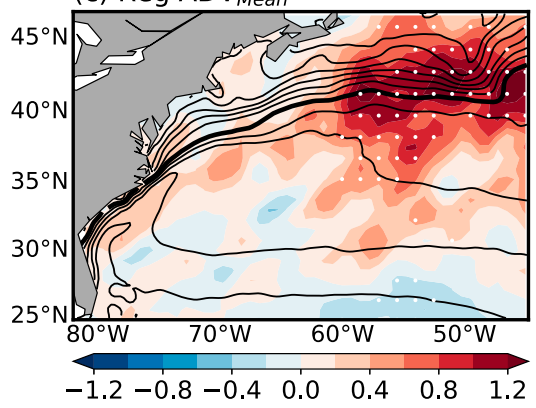

(f) Reg ADV $V_{\text {Syn }}$

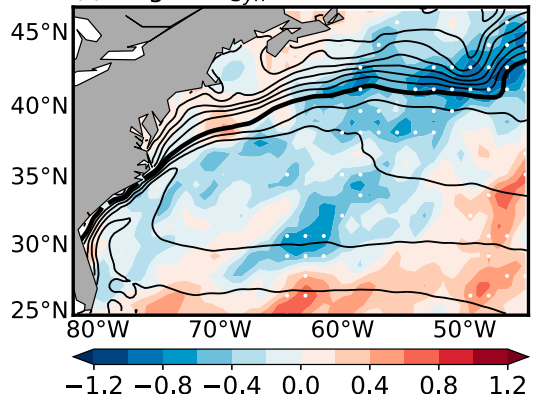

FIG. 9. Regressions (color shading, $\mathrm{mm} \mathrm{day}^{-1}$ ) of the terms in the moisture budget equation onto PC1 based upon ERA5: (a) precipitation, (b) mean-flow moisture convergence, (c) mean-flow moisture advection, (d) evaporation, (e) synoptic moisture convergence, (f) synoptic moisture advection, and (g) residual. The white rectangle in (a) represents the domain within which regional averages are calculated.

due to the SST - SAT variation resembles that of evaporation, and the effect of SST - SAT is much greater than that of wind speed. We also examine the effects of sea-air humidity difference, which is negligible in magnitude compared with the effects of variations in SST - SAT and surface wind speed (not shown). The SST - SAT is positive over the Gulf Stream axis west of $65^{\circ} \mathrm{W}$ (Fig. 11b), and the regressed precipitation shows maximum values in this region (Fig. 9a). Interannual variability of the frontal precipitation might be partly due to the Gulf Stream variability related to the NAO. The positive NAO phase favors stronger westerly and trade winds, and more northerly separation points and paths of the Gulf Stream (Taylor and Stephens 1998; Frankignoul et al. 2001; Wolfe et al. 2019). These excursions are related to Sverdrup responses to latitudinal shifts of the zero-wind stress curl line and adjustments to Ekman transports (Parsons 1969; Veronis 1973; Gangopadhyay et al. 1992; Taylor and Stephens. 1998), which introduce a delay to the Gulf Stream response

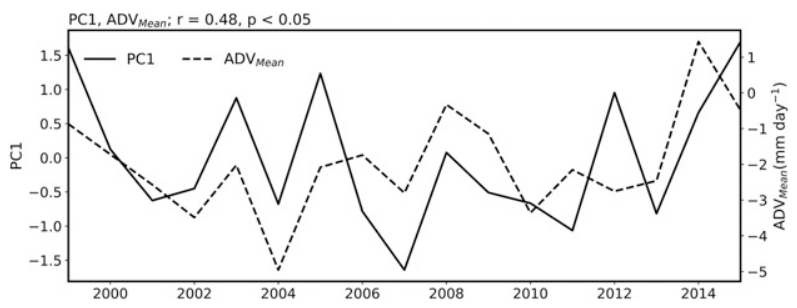

FIG. 10. Time series of PC1 (solid line) and vertically integrated mean-flow moisture advection (dashed line, $\mathrm{mm} \mathrm{day}^{-1}$ ) averaged over the white rectangle in Fig. 9a. 
(a) Reg SST $\left({ }^{\circ} \mathrm{C}\right), \vec{u}_{10 m}\left(\mathrm{~m} \mathrm{~s}^{-1}\right)$

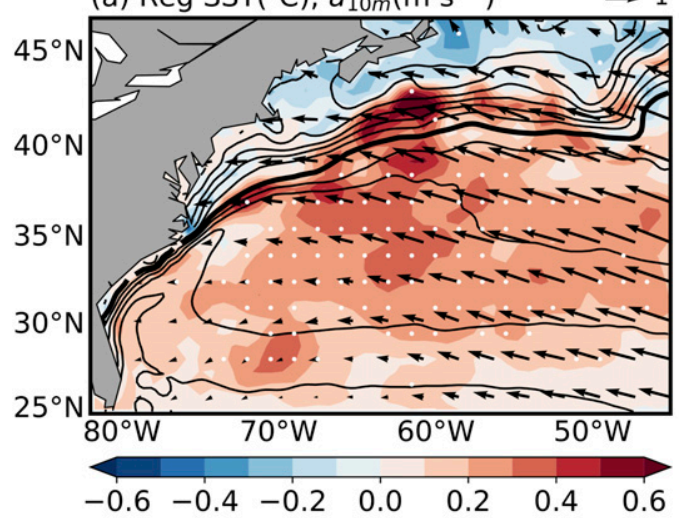

(c) Reg Wind effect $\left(\mathrm{mm} \mathrm{day}^{-1}\right)$

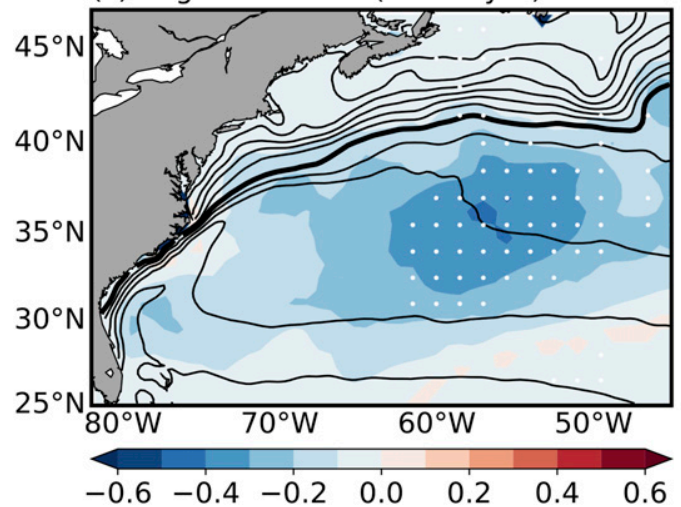

(b) Reg SST-SAT $\left({ }^{\circ} \mathrm{C}\right)$

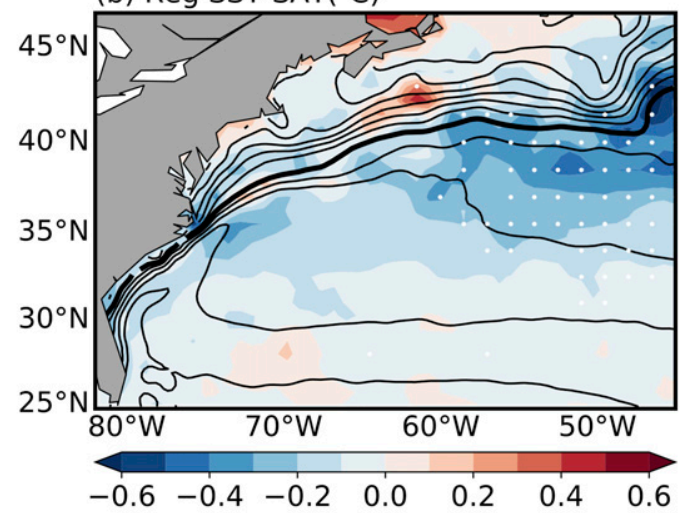

(d) Reg SST-SAT effect $\left(\mathrm{mm} \mathrm{day}^{-1}\right)$

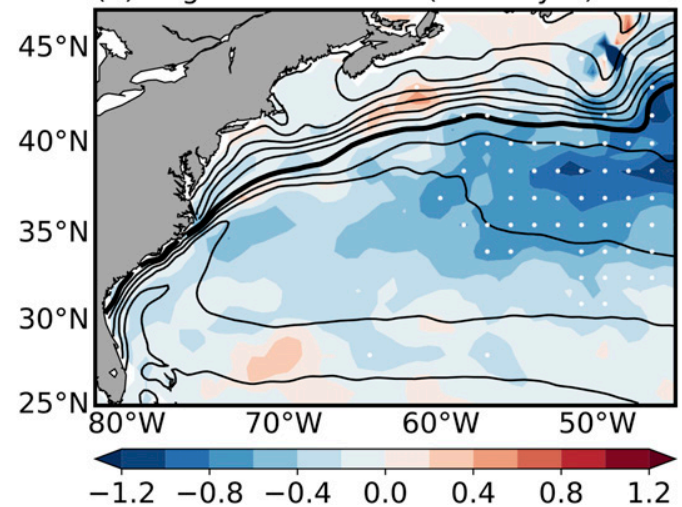

FIG. 11. Regressions against the PC1: (a) SST (color shading, ${ }^{\circ} \mathrm{C}$ ) and surface wind velocities (vectors, $\mathrm{m} \mathrm{s}^{-1}$ ), (b) SST - SAT (color shading, ${ }^{\circ} \mathrm{C}$ ), and the effects of variations in (c) surface winds and (d) SST - SAT on evaporation (color shading, $\mathrm{mm} \mathrm{day}^{-1}$ ).

that is best related to the NAO forcing at lags of 0-2 years (Hurrell et al. 2003). The regressed residual is not ignorable over the northeast Atlantic but lacks an apparent pattern associated with the SST front (Fig. 9g). This is due to the moisture imbalance in the reanalysis data and time scale gap between 8 days and 1 month.

In winter climatology, precipitation over the Gulf Stream is generally supported by evaporation and weakened by the mean-flow moisture advection, which is induced by the prevailing northwesterlies. At the interannual time scale, by contrast, evaporation and mean-flow moisture advection turn into negative and positive contributors to precipitation increase over the Gulf Stream, respectively. Mean-flow moisture convergence positively contributes to the increased precipitation area where climatological counterpart is also large. Synoptic activity also plays an important role in the moisture budget. Synoptic moisture convergence (advection) supports (decreases) moisture for the precipitation band in climatology, and has the same effect when the precipitation increases with the synoptic activity strengthened and shifted to the north over the Gulf
Stream area at the interannual time scale. Since the PC1 is also correlated with the NAO index, the NAO circulation strongly affects the precipitation over the Gulf Stream through modulating the evaporation, mean-flow effects, and storm activities. Over the white rectangle in Fig. 9a, the averaged positive contributions of meanflow moisture advection, mean-flow moisture convergence, and synoptic moisture convergence are $281.0 \%$, $65.7 \%$, and $67.2 \%$, respectively. So the positive precipitation anomaly over the Gulf Stream largely results from the variation in weakened mean-flow moisture advection associated with positive NAO. The negative contributions of evaporation and synoptic moisture advection are $-141.5 \%$ and $-175.3 \%$, respectively. The contribution of the residual is $2.9 \%$. Since the horizontal resolution of the SST data used to prepare the reanalysis data in ERA5 changed from $0.25^{\circ}$ to $0.05^{\circ}$ on August 2007 (Hersbach et al. 2018), the data we use in this study contain 9 years of $0.25^{\circ}$ resolution and 8 years of $0.05^{\circ}$ resolution. We further examined the mean values (Fig. 3) and regressions (Fig. 9) of terms in moisture budgets from 2008 to 2015, and found that the spatial 
patterns and magnitudes are similar to those since 1999. We verified the robustness of moisture budget results based on ERA5 using ERA-Interim and the Japanese 55-year Reanalysis, and found that the above results are not sensitive to the choice of dataset (not shown).

\section{SLP adjustment and synoptic activities}

The above analysis reveals a close relationship between the wintertime precipitation over the Gulf Stream and NAO in terms of moisture budget. This section further investigates how NAO modulates the precipitation over the Gulf Stream in dynamics. The SLP adjustment mechanism is thought to be the primary cause of the precipitation band over the Gulf Stream (Minobe et al. 2008). Surface wind convergences are affected by the SLP adjustments to SST gradients. The correspondence between surface wind convergence and SLP unveils the SST frontal effect on marine atmospheric boundary layer in climatology. Spatial patterns of the SLP Laplacian ( $\Delta$ SLP) are similar to those of the SST Laplacian $(\Delta S S T)$ in climatological fields, and the effect of SLP adjustment can be revealed by the correlation coefficient between $\triangle$ SLP and surface wind convergence (Minobe et al. 2008). The 17-yr mean spatial correlation of $\triangle \mathrm{SLP}$ and $\Delta \mathrm{SST}$ is 0.58 , and the maximum and minimum of annual correlations are 0.64 and 0.50 , respectively. Thus, the relationship between $\triangle$ SLP and $\Delta$ SST is also at work on interannual variability. The correlation coefficient between $\Delta$ SLP and surface wind convergence reflects the response intensity of surface wind convergence to SLP adjustment (Minobe et al. 2008). We use correlation coefficients between $\Delta$ SLP and surface wind convergence within $30^{\circ}-42^{\circ} \mathrm{N}, 75^{\circ}-$ $50^{\circ} \mathrm{W}$ to quantify SLP adjustment intensities. Figure $12 \mathrm{a}$ shows that the NAO index and SLP adjustment intensity over the Gulf Stream are correlated $(r=0.60, p<0.05)$, suggesting that the SLP adjustment intensifies during positive NAO phase and weakens during negative NAO phase. This result is consistent with the results of $\mathrm{Xu}$ and $\mathrm{Xu}$ (2015) showing that the SLP adjustment dominates when the winds blow along the axis of the Kuroshio in the East China Sea.

A closer examination shows that the correspondence between observed SST gradient and surface wind convergence is not consistently strong along the SST front (not shown). Minobe et al. (2008) suggested that the relationship between the two is also modulated by the surface pressure and boundary layer depth, which are greatly variable along the Gulf Stream (Liu et al. 2014). Actually, the surface convergence also partly originates from the convergence above the boundary layer, which is also affected by the latent heat release from
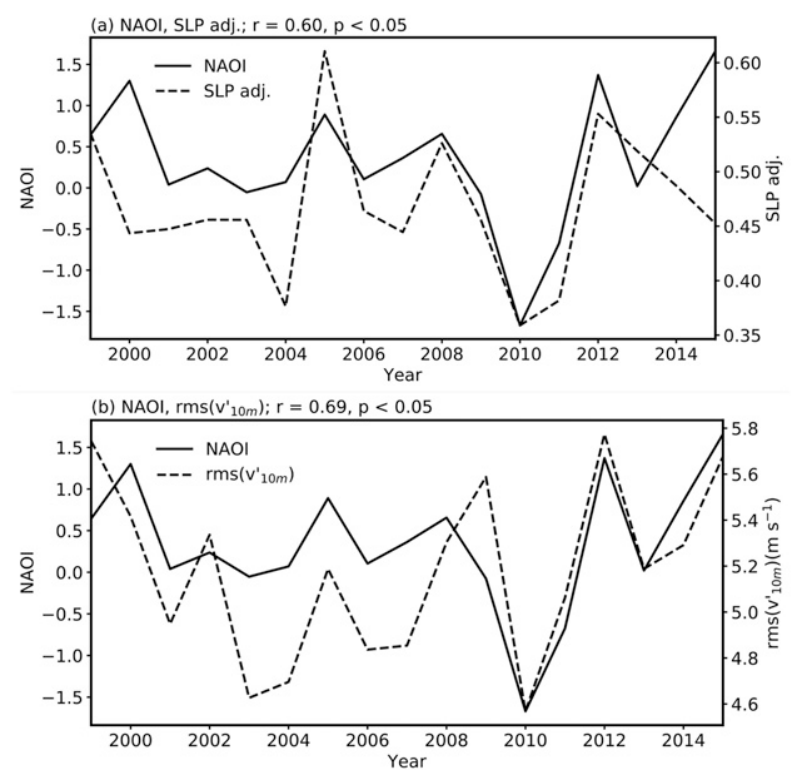

FIG. 12. (a) Time series of NAO index (solid line) and the intensity of SLP adjustment (dashed line) calculated over $30^{\circ}-42^{\circ} \mathrm{N}$, $75^{\circ}-50^{\circ} \mathrm{W}$ based on the ERA5. (b) Time series of NAO index (solid line) and the averaged root-mean-square of 10-m meridional wind velocity fluctuation (dashed line, $\mathrm{m} \mathrm{s}^{-1}$ ) over the white rectangle in based on the ERA5.

precipitation. In addition, the uneven sampling between the satellites observing SST and surface winds may also contribute to the inconsistency between the SST gradient and wind convergence.

The correlation coefficient between SLP adjustment and NAO index is 0.60 , indicating that about $64 \%$ of SLP adjustment variance should be explained by mechanisms other than the anomalous monthly mean surface wind related to the NAO. Higher (lower) eddy kinetic energy intensity is observed in the Gulf Stream region during positive (negative) NAO phases, and provides a greater (lesser) source of baroclinic instability to the Gulf Stream front; see Chaudhuri et al. (2009). The effect of synoptic activities on moisture budget over the Gulf Stream implies potential influences of transient eddies on surface wind convergence, upward motion, and precipitation.

Figure $4 \mathrm{~b}$ shows that the regressed rms of $10-\mathrm{m}$ meridional wind velocity fluctuation onto $\mathrm{PC} 1$ is positive over the Gulf Stream SST front and negative to the southeast of the Gulf Stream. This implies enhanced synoptic activities over the SST front, and is directly related to the spatial pattern of EOF1 (Fig. 5a). We also use the regressions of local deepening rate (KuwanoYoshida 2014) and Eady growth rate (Lindzen and Farrell 1980) at $900 \mathrm{hPa}$ onto the NAO index to verify the robustness of the result (not shown). Different forms of synoptic activity expression imply intensified and 
north-shifted storm activities over the Gulf Stream area during the positive NAO phase. The abnormal synoptic activities near the Gulf Stream contribute to the surface convergence and precipitation over the SST front. The correlation coefficient of the NAO index and mean rms of $10-\mathrm{m}$ meridional wind velocity fluctuation over the white rectangle in Fig. 9a is 0.69 , which is significant at the $95 \%$ confidence level (Fig. 12b).

Vannière et al. (2017) investigated whether the mean ascent over the warm SST front results from frequent weak subsidence and less frequent strong ascent, which is related to the convective precipitation over the area where cold advection occurs. O'Neill et al. (2017) also showed that storms propagating along the storm track that overlies the Gulf Stream produce the time-mean surface convergence zone in climatology. Our result reveals that the variations of DJF surface convergence and SLP adjustment intensity are partly related to the variations of synoptic activities along the SST front at the interannual time scale. The correlation coefficient of SLP adjustment intensity and mean rms of $10-\mathrm{m}$ meridional wind velocity fluctuation over the white rectangle is 0.6 , which is not significant. The Gulf Stream SST gradient is important for storm development in North Atlantic (Parfitt et al. 2016). Despite the effect of the NAO, abnormal synoptic activities in the north of the Gulf Stream SST front may be partly related to the strengthened SST gradient on the cold flank of the SST front (not shown). The mean SLP adjustment intensities are 0.51 and 0.52 during $1997-2007$ and $2008-18$, respectively. This implies that the resolution of prescribed SST in ERA5 has little effect on SLP adjustment intensity.

\section{Summary and discussion}

In winter, the Gulf Stream anchors a salient precipitation band over the warm flank of the SST front. Previous studies suggested that the SLP adjustment is responsible for the precipitation band (Minobe et al. $2008,2010)$. This study focuses on the interannual precipitation variation over the Gulf Stream in winter. The results show that the wintertime precipitation exhibits stronger variability over the Gulf Stream SST front, and the atmospheric circulation and synoptic activities related to NAO play important roles in modulating the precipitation there.

The EOF analysis is applied to analyze the interannual DJF precipitation over the Gulf Stream. EOF1 depicts the precipitation variation over the Gulf Stream proper, and PC1 is correlated with the NAO index. To confirm the relationship between the NAO and the precipitation over the Gulf Stream in winter, we regress
500-hPa geopotential height and SLP onto PC1. The results show a barotropic dipolar pattern with peaks over Iceland and the Azores, respectively, that is quite similar to the NAO pattern (Barnston and Livezey 1987). The regressed DJF observed precipitation onto the NAO index also shows that the precipitation over the Gulf Stream front increases by $\sim 2 \mathrm{~mm}$ day $^{-1}$ during the positive NAO phase.

We interpret how the NAO circulation modulates the precipitation over the Gulf Stream from the perspective of moisture budget. In wintertime climatology, the evaporation peaks just over the Florida Current and reaches up to $10 \mathrm{~mm}$ day $^{-1}$ (Fig. $3 \mathrm{~d}$ ). The strong evaporation generally supports the downstream precipitation band under northwesterlies. The mean-flow moisture advection induced by the prevailing westerlies moves the evaporated moisture downstream and weakens the precipitation band (Fig. 3c). At the interannual time scale, by contrast, the decreased mean-flow moisture advection positively contributes to the precipitation over the Gulf Stream due to the weakened prevailing winds during positive NAO. The anomalous southeasterlies also reduce the evaporation primarily because of the decrease in SST - SAT (Fig. 11d). Synoptic activities play an important role in moisture budget. The synoptic moisture convergence (advection) has a positive (negative) contribution to the precipitation band due to the synoptic activities with the maximum over the SST front in climatology. With the enhancement of synoptic activity over the SST front during positive NAO phase, the synoptic convergence (advection) positively (negatively) contributes to the precipitation over the SST front.

In addition, the mean flow and synoptic moisture convergence make weak positive contributions to the precipitation band both in climatology and at the interannual time scale, indicative of a positive feedback between precipitation and boundary layer convergence over the Gulf Stream. The SST front creates a convergence zone over the Gulf Stream through SLP adjustment mechanism. The induced upward motion increases the precipitation and releases latent heat in the lower atmosphere in winter (Minobe et al. 2010). The latent heating in turn intensifies the surface convergence zone. Further studies are needed to fully resolve the hydrologic cycle including synoptic activities in the reanalysis data.

We employ the correlation coefficient between $\triangle$ SLP and surface wind convergence to quantify the variation in SLP adjustment strength associated with NAO in winter. The result shows that SLP adjustment significantly intensifies (slackens) during positive (negative) NAO when the precipitation increases (decreases) over 
the Gulf Stream SST front. This implies the SLP adjustment mechanism is also at work at the interannual time scale.

Synoptic storms frequently travel along the storm track over the Gulf Stream, accompanied by strong surface convergence (O'Neill et al. 2017). We have examined the variations in winter synoptic activities in relation to NAO near the Gulf Stream between 1999 and 2015. The results based on different metrics all imply intensified and north-shifted synoptic activities over the Gulf Stream area during positive NAO phase according to their climatology. The intensified and north-shifted synoptic activities near the Gulf Stream are related to the stronger surface convergence over the SST front, and contribute to the enhancement of SLP adjustment.

Besides the NAO's influence on the Gulf Stream frontal precipitation, extratropical cyclones occurring along the Gulf Stream can also have a sudden and significant effect on the Atlantic mean circulation and push the jet poleward or southward. Even single storms can trigger important NAO events by breaking at the end of their life cycle (Rivière and Orlansik 2007). The potential effects of the precipitation variation along the Gulf Stream onto large-scale atmospheric circulations are still not well understood at the interannual time scale.

Acknowledgments. This work is supported by the National Key Research and Development Program of China (2018YFA0605700), the Natural Science Foundation of China (41875012), and Shandong Natural Science Foundation Project (ZR2019ZD12). We appreciate three anonymous reviewers for their insightful and constructive comments. The data used in this study are obtained from the NASA Goddard Space Flight Center's Mesoscale Atmospheric Processes Laboratory and Precipitation Processing System (TMPA), the Remote Sensing Systems (CCMP and SSMI/SSMIS), the ECMWF data server (ERA5), the NOAA CoastWatch East Coast Node (AVHRR), and NOAA Climate Prediction Center (NAO index).

\section{REFERENCES}

Atlas, R., R. N. Hoffman, J. Ardizzone, S. M. Leidner, J. C. Jusem, D. K. Smith, and D. Gombos, 2011: A crosscalibrated, multiplatform ocean surface wind velocity product for meteorological and oceanographic applications. Bull. Amer. Meteor. Soc., 92, 157-174, https://doi.org/ 10.1175/2010BAMS2946.1.

Bane, J. M., Jr., and K. E. Osgood, 1989: Wintertime air-sea interaction processes across the Gulf Stream. J. Geophys. Res. 94, $10755-10772$, https://doi.org/10.1029/JC094iC08p10755.

Barnston, A. G., and R. E. Livezey, 1987: Classification, seasonality and persistence of low-frequency atmospheric circulation patterns. Mon. Wea. Rev., 115, 1083-1126, https://doi.org/ 10.1175/1520-0493(1987)115<1083:CSAPOL > 2.0.CO;2.

Bartlett, M., 1935: Some aspects of the time-correlation problem in regard to tests of significance. J. Roy. Stat. Soc., 98, 536-543, https://doi.org/10.2307/2342284.

Berrisford, P., P. Kållberg, S. Kobayashi, D. Dee, S. Uppala, A. J. Simmons, P. Poli, and H. Sato, 2011: Atmospheric conservation properties in ERA-Interim. Quart. J. Roy. Meteor. Soc., 137, 1381-1399, https://doi.org/10.1002/qj.864.

Chaudhuri, A. H., A. Gangopadhyay, and J. J. Bisagni, 2009: Interannual variability of Gulf Stream warm-core rings in response to the North Atlantic Oscillation. Cont. Shelf Res., 29, 856-869, https://doi.org/10.1016/j.csr.2009.01.008.

Copernicus Climate Change Service, 2017: ERA5: Fifth generation of ECMWF atmospheric reanalysis of the global climate. Copernicus Climate Change Service Climate Data Store, accessed 23 April 2019, https://cds.climate.copernicus.eu/cdsapp\#!/dataset/reanalysisera5-single-levels-monthly-means?tab=form.

Ducet, N., P. Y. L. Traon, and G. Reverdin, 2000: Global highresolution mapping of ocean circulation from TOPEX/ Poseidon and ERS-1 and -2. J. Geophys. Res., 105, 1947719498, https://doi.org/10.1029/2000JC900063.

Feng, X., B. Huang, B. P. Kirtman, J. L. Kinter, and L. S. Chiu, 2017: A multi-model analysis of the resolution influence on precipitation climatology in the Gulf Stream region. Climate Dyn., 48, 1685-1704, https://doi.org/10.1007/s00382-016-3167-7.

Forbes, J. M., M. E. Hagan, X. Zhang, and K. Hamilton, 1997: Upper atmosphere tidal oscillations due to latent heat release in the tropical troposphere. Ann. Geophys., 15, 1165-1175, https://doi.org/10.1007/s00585-997-1165-0.

Frankignoul, C., G. de Coëtlogon, T. M. Joyce, and S. Dong, 2001: Gulf Stream variability and ocean-atmosphere interactions. J. Phys. Oceanogr., 31, 3516-3529, https://doi.org/10.1175/ 1520-0485(2002)031<3516:GSVAOA > 2.0.CO;2.

Gangopadhyay, A., P. Cornillon, and D. R. Watts, 1992: A test of the Parsons-Veronis hypothesis on the separation of the Gulf Stream. J. Phys. Oceanogr., 22, 1286-1301, https://doi.org/ 10.1175/1520-0485(1992)022<1286:ATOTPH>2.0.CO;2.

Hamilton, K., 1981: Latent heat release as a possible forcing mechanism for atmospheric tides. Mon. Wea. Rev., 109, 3-17, https://doi.org/ 10.1175/1520-0493(1981)109<0003:LHRAAP > 2.0.CO;2.

Hand, R., N. Keenlyside, N.-E. Omrani, and M. Latif, 2014: Simulated response to inter-annual SST variations in the Gulf Stream region. Climate Dyn., 42, 715-731, https://doi.org/ 10.1007/s00382-013-1715-y.

Hersbach, H., and Coauthors, 2018: Operational global reanalysis: Progress, future directions and synergies with NWP. ERA Rep. Series 27, 63 pp., https://www.ecmwf.int/node/18765.

Hirata, H., R. Kawamura, M. Nonaka, and K. Tsuboki, 2019: Significant impact of heat supply from the Gulf Stream on a "super bomb" cyclone in January 2018. Geophys. Res. Lett., 46, 7718-7725, https://doi.org/10.1029/2019GL082995.

Hobbs, P. V., 1987: The Gulf Stream rainband. Geophys. Res. Lett., 14, 1142-1145, https://doi.org/10.1029/GL014i011p01142.

Huffman, G. J., and Coauthors, 2007: The TRMM Multisatellite Precipitation Analysis (TMPA): Quasi-global, multiyear, combined-sensor precipitation estimates at fine scales. J. Hydrometeor., 8, 38-55, https://doi.org/10.1175/JHM560.1.

Hurrell, J. W., 1995: Decadal trends in the North Atlantic Oscillation: Regional temperatures and precipitation. Science, 269, 676-679, https://doi.org/10.1126/science.269.5224.676. , Y. Kushnir, G. Ottersen, and M. Visbeck, 2003: An overview of the North Atlantic Oscillation. The North Atlantic 
Oscillation: Climatic Significance and Environmental Impact, Geophys. Monogr., Vol. 134, Amer. Geophys. Union, 1-35, https://doi.org/10.1029/134GM01.

Jakobson, E., and T. Vihma, 2010: Atmospheric moisture budget in the Arctic based on the ERA-40 reanalysis. Int. J. Climatol., 30, 2175-2194, https://doi.org/10.1002/joc.2039.

Joyce, T. M., Y.-O. Kwon, and L. Yu, 2009: On the relationship between synoptic wintertime atmospheric variability and path shifts in the Gulf Stream and the Kuroshio Extension. J. Climate, 22, 3177-3192, https://doi.org/10.1175/ 2008JCLI2690.1.

Kuwano-Yoshida, A., 2014: Using the local deepening rate to indicate extratropical cyclone activity. SOLA, 10, 199-203, https://doi.org/10.2151/SOLA.2014-042.

— the northwestern Pacific region in an AGCM. J. Climate, 30, 1081-1102, https://doi.org/10.1175/JCLI-D-16-0331.1.

Kwon, B. H., B. Bénech, D. Lambert, P. Durand, A. Druilhet, H. Giordani, and S. Planton, 1998: Structure of the marine atmospheric boundary layer over an oceanic thermal front: SEMAPHORE experiment. J. Geophys. Res., 103, 25159 25 180, https://doi.org/10.1029/98JC02207.

Li, Y., J. Li, and J. Feng, 2012: A teleconnection between the reduction of rainfall in southwest Western Australia and North China. J. Climate, 25, 8444-8461, https://doi.org/10.1175/JCLID-11-00613.1.

Lindzen, R. S., and B. Farrell, 1980: A simple approximate result for the maximum growth rate of baroclinic instabilities. J. Atmos. Sci., 37, 1648-1654, https://doi.org/10.1175/15200469(1980)037,1648:ASARFT.2.0.CO;2.

, and S. Nigam, 1987: On the role of sea surface temperature gradients in forcing low-level winds and convergence in the tropics. J. Atmos. Sci., 44, 2418-2436, https://doi.org/10.1175/ 1520-0469(1987)044<2418:OTROSS > 2.0.CO;2.

Liu, J.-W., S.-P. Xie, J. R. Norris, and S.-P. Zhang, 2014: Low-level cloud response to the Gulf Stream front in winter using CALIPSO. J. Climate, 27, 4421-4432, https://doi.org/10.1175/ JCLI-D-13-00469.1.

Ma, X., and Coauthors, 2015: Distant influence of Kuroshio eddies on North Pacific weather patterns? Sci. Rep., 5, 17785, https:// doi.org/10.1038/srep17785.

_ , and Coauthors, 2016: Western boundary currents regulated by interaction between ocean eddies and the atmosphere. Nature, 535, 533-537, https://doi.org/10.1038/nature18640.

Minobe, S., A. Kuwano-Yoshida, N. Komori, S.-P. Xie, and R. J. Small, 2008: Influence of the Gulf Stream on the troposphere. Nature, 452, 206-209, https://doi.org/10.1038/nature06690.

-, M. Miyashita, A. Kuwano-Yoshida, H. Tokinaga, and S.-P. Xie, 2010: Atmospheric response to the Gulf Stream: Seasonal variations. J. Climate, 23, 3699-3719, https://doi.org/10.1175/ 2010JCLI3359.1.

Nakamura, H., A. Nishina, and S. Minobe, 2012: Response of storm tracks to bimodal Kuroshio path states south of Japan. J. Climate, 25, 7772-7779, https://doi.org/10.1175/JCLI-D-12-00326.1.

Norris, J. R., 1998: Low cloud type over the ocean from surface observations. Part I: Relationship to surface meteorology and the vertical distribution of temperature and moisture. J. Climate, 11, 369-382, https://doi.org/10.1175/1520-0442(1998) $011<0369:$ LCTOTO $>2.0$. CO;2.

, and S. F. Iacobellis, 2005: North Pacific cloud feedbacks inferred from synoptic-scale dynamic and thermodynamic relationships. J. Climate, 18, 4862-4878, https://doi.org/10.1175/ JCLI3558.1.
O'Neill, L. W., T. Haack, D. B. Chelton, and E. Skyllingstad, 2017: The Gulf Stream convergence zone in the time-mean winds. J. Atmos. Sci., 74, 2383-2412, https://doi.org/10.1175/JAS-D16-0213.1.

O'Reilly, C. H., and A. Czaja, 2015: The response of the Pacific storm track and atmospheric circulation to Kuroshio Extension variability. Quart. J. Roy. Meteor. Soc., 141, 52-66, https://doi.org/10.1002/qj.2334.

Parfitt, R., A. Czaja, S. Minobe, and A. Kuwano-Yoshida, 2016: The atmospheric frontal response to SST perturbations in the Gulf Stream region. Geophys. Res. Lett., 43, 2299-2306, https://doi.org/10.1002/2016GL067723.

Parsons, A. T., 1969: A two-layer model of Gulf Stream separation. J. Fluid Mech., 39, 511-528, https://doi.org/10.1017/ S0022112069002308.

Pfahl, S., C. Schwierz, M. Croci-Maspoli, C. M. Grams, and H. Wernli, 2015: Importance of latent heat release in ascending air streams for atmospheric blocking. Nat. Geosci., 8 , 610-614, https://doi.org/10.1038/ngeo2487.

Philander, S. G., and A. D. Seigel, 1985: Simulation of El Niño of 1982-1983. Coupled Ocean-Atmosphere Models, J. C. J. Nihoul, Ed., Elsevier Oceanography Series, Vol. 40, Elsevier, 517-541, https://doi.org/10.1016/S0422-9894(08)70729-3.

Pyper, B. J., and R. M. Peterman, 1998: Comparison of methods to account for autocorrelation in correlation analyses of fish data. Can. J. Fish. Aquat. Sci., 55, 2127-2140, https://doi.org/ 10.1139/f98-104.

Rivière, G., and I. Orlanski, 2007: Characteristics of the Atlantic storm-track eddy activity and its relation with the North Atlantic Oscillation. J. Atmos. Sci., 64, 241-266, https:// doi.org/10.1175/JAS3850.1.

Salah, Z., R. Nieto, A. Drumond, L. Gimeno, and S. M. VicenteSerrano, 2018: A Lagrangian analysis of the moisture budget over the Fertile Crescent during two intense drought episodes. J. Hydrol., 560, 382-395, https://doi.org/10.1016/ j.jhydrol.2018.03.021.

Sampe, T., H. Nakamura, A. Goto, and W. Ohfuchi, 2010: Significance of a midlatitude SST frontal zone in the formation of a storm track and an eddy-driven westerly jet. J. Climate, 23, 1793-1814, https://doi.org/10.1175/2009JCLI3163.1.

Sasaki, Y. N., and Y. Yamada, 2018: Atmospheric response to interannual variability of sea surface temperature front in the East China Sea in early summer. Climate Dyn., 51, 2509-2522, https://doi.org/10.1007/s00382-017-4025-y.

Seager, R., and N. Henderson, 2013: Diagnostic computation of moisture budgets in the ERA-Interim reanalysis with reference to analysis of CMIP-archived atmospheric model data. J. Climate, 26, 7876-7901, https://doi.org/10.1175/JCLI-D-13-00018.1.

_ , N. Naik, and G. A. Vecchi, 2010: Thermodynamic and dynamic mechanisms for large-scale changes in the hydrological cycle in response to global warming. J. Climate, $\mathbf{2 3}, 4651-4668$, https://doi.org/10.1175/2010JCLI3655.1.

Sheldon, L., A. Czaja, B. Vannière, C. Morcrette, B. Sohet, M. Casado, and D. Smith, 2017: A 'warm path' for Gulf Stream-troposphere interactions. Tellus, 69A, 1299397, https://doi.org/10.1080/16000870.2017.1299397.

Small, R. J., R. A. Tomas, and F. O. Bryan, 2014: Storm track response to ocean fronts in a global high-resolution climate model. Climate Dyn., 43, 805-828, https://doi.org/10.1007/ s00382-013-1980-9.

Spall, M. A., 2007: Midlatitude wind stress-sea surface temperature coupling in the vicinity of oceanic fronts. J. Climate, 20, 3785-3801, https://doi.org/10.1175/JCLI4234.1. 
Sugimoto, S., K. Aono, and S. Fukui, 2017: Local atmospheric response to warm mesoscale ocean eddies in the KuroshioOyashio Confluence region. Sci. Rep., 7, 11871, https://doi.org/ 10.1038/s41598-017-12206-9.

Taguchi, B., H. Nakamura, M. Nonaka, and S.-P. Xie, 2009: Influences of the Kuroshio/Oyashio Extensions on air-sea heat exchanges and storm-track activity as revealed in regional atmospheric model simulations for the 2003/04 cold season. J. Climate, 22, 6536-6560, https://doi.org/10.1175/ 2009JCLI2910.1.

,,,-- N. Komori, A. Kuwano-Yoshida, K. Takaya, and A. Goto, 2012: Seasonal evolutions of atmospheric response to decadal SST anomalies in the North Pacific Subarctic frontal zone: Observations and a coupled model simulation. J. Climate, 25, 111-139, https://doi.org/10.1175/JCLI-D-11-00046.1.

Taylor, A. H., and J. A. Stephens, 1998: The North Atlantic Oscillation and the latitude of the Gulf Stream. Tellus, $\mathbf{5 0 A}$, 134-142, https://doi.org/10.3402/tellusa.v50i1.14517.

Tietäväinen, H., and T. Vihma, 2008: Atmospheric moisture budget over Antarctica and the Southern Ocean based on the ERA-40 reanalysis. Int. J. Climatol., 28, 1977-1995, https:// doi.org/10.1002/joc.1684.

Tokinaga, H., Y. Tanimoto, S.-P. Xie, T. Sampe, H. Tomita, and H. Ichikawa, 2009: Ocean frontal effects on the vertical development of clouds over the western North Pacific: In situ and satellite observations. J. Climate, 22, 4241-4260, https:// doi.org/10.1175/2009JCLI2763.1.

Tomczak, M., and J. S. Godfrey, 2003: Regional Oceanography: An Introduction. 2nd ed. Daya Publishing House, 390 pp.

Trenberth, K. E., and C. J. Guillemot, 1995: Evaluation of the global atmospheric moisture budget as seen from analyses. J. Climate, 8, 2255-2272, https://doi.org/10.1175/1520-0442(1995) $008<2255$ :EOTGAM $>2.0$. CO;2.

_, J. T. Fasullo, and J. Mackaro, 2011: Atmospheric moisture transports from ocean to land and global energy flows in reanalyses. J. Climate, 24, 4907-4924, https://doi.org/10.1175/ 2011JCLI4171.1.

Vannière, B., A. Czaja, H. Dacre, and T. Woollings, 2017: A "cold path" for the Gulf Stream-troposphere connection. J. Climate, 30, 1363-1379, https://doi.org/10.1175/JCLI-D15-0749.1.

Veronis, G., 1973: Model of the world ocean circulation: I. Winddriven, two layer. J. Mar. Res., 31, 228-288.

Wang, J., and L. Y. Oey, 2016: Seasonal exchanges of the Kuroshio and shelf waters and their impacts on the shelf currents of the East China Sea. J. Phys. Oceanogr., 46, 1615-1632, https:// doi.org/10.1175/JPO-D-15-0183.1.

Wang, Z., and I. Hankes, 2016: Moisture and precipitation evolution during tropical cyclone formation as revealed by the SSM/ I-SSMIS retrievals. J. Atmos. Sci., 73, 2773-2781, https:// doi.org/10.1175/JAS-D-15-0306.1.

Wolfe, C. L. P., S. Hameed, and L. Chi, 2019: On the drivers of decadal variability of the Gulf Stream north wall. J. Climate, 32, 1235-1249, https://doi.org/10.1175/JCLI-D-18-0212.1.

Xie, S.-P., and S. G. H. Philander, 1994: A coupled oceanatmosphere model of relevance to the ITCZ in the eastern Pacific. Tellus, 46A, 340-350, https://doi.org/10.3402/ tellusa.v46i4.15484.

Xu, H., M. Xu, S.-P. Xie, and Y. Wang, 2011: Deep atmospheric response to the spring Kuroshio over the East China Sea. J. Climate, 24, 4959-4972, https://doi.org/10.1175/JCLI-D-1005034.1.

$\mathrm{Xu}, \mathrm{M}$., and $\mathrm{H}$. Xu, 2015: Atmospheric responses to Kuroshio SST front in the East China Sea under different prevailing winds in winter and spring. J. Climate, 28, 3191-3211, https://doi.org/ 10.1175/JCLI-D-13-00675.1.

Zar, J. H., 1984: Biostatistical Analysis. Prentice Hall, 718 pp.

Zwiers, F. W., and H. von Storch, 1995: Taking serial correlation into account in tests of the mean. J. Climate, 8, 336-351, https://doi.org/ 10.1175/1520-0442(1995)008<0336:TSCIAI >2.0.CO;2. 